NBER WORKING PAPER SERIES

TAXES AND TIME ALLOCATION: EVIDENCE FROM SINGLE WOMEN

\author{
Alexander M. Gelber \\ Joshua W. Mitchell \\ Working Paper 15583 \\ http://www.nber.org/papers/w15583
NATIONAL BUREAU OF ECONOMIC RESEARCH
1050 Massachusetts Avenue
Cambridge, MA 02138 \\ December 2009
}

\begin{abstract}
We thank Raj Chetty, David Cutler, Daniel Hamermesh, Erik Hurst, Lawrence Katz, Louis Kaplow, Bruce Meyer, Claudia Olivetti, Daniel Sacks, Karl Scholz, Daniel Silverman, Todd Sinai, Justin Wolfers, and seminar participants at Harvard, IIES, NBER, the National Tax Association, the Nordic Summer Institute in Empirical Labor Economics, SOFI, Stanford, the Stockholm School of Economics, UBC, the University of Wisconsin-Madison, Uppsala, and Wharton for suggestions. We are grateful to Adam Looney, Bruce Meyer, and Mel Stephens for generously sharing data. We are also grateful to Mark Aguiar and Erik Hurst for making their data and code available on the web. Daniel Sacks provided outstanding research assistance. Gelber acknowledges financial support from the National Institute on Aging, Grant Number T32-AG00186. All errors are our own. Email: agelber@nber.org. The views expressed herein are those of the author(s) and do not necessarily reflect the views of the National Bureau of Economic Research.
\end{abstract}

NBER working papers are circulated for discussion and comment purposes. They have not been peerreviewed or been subject to the review by the NBER Board of Directors that accompanies official NBER publications.

(C) 2009 by Alexander M. Gelber and Joshua W. Mitchell. All rights reserved. Short sections of text, not to exceed two paragraphs, may be quoted without explicit permission provided that full credit, including $(\odot)$ notice, is given to the source. 
Taxes and Time Allocation: Evidence from Single Women

Alexander M. Gelber and Joshua W. Mitchell

NBER Working Paper No. 15583

December 2009

JEL No. E32,H2,H24,H3,J22

\begin{abstract}
$\underline{\text { ABSTRACT }}$
Hundreds of papers have investigated how incentives and policies affect hours worked in the market. This paper examines how income taxes affect time allocation in the other two-thirds of the day. Using the Panel Study of Income Dynamics from 1975 to 2004, we analyze the response of single women's housework, labor supply, and other time to variation in tax and transfer schedules across income levels, number of children, states, and time. We find that when the economic reward to participating in the labor force increases, market work increases and housework decreases, with the decrease in housework accounting for approximately two-thirds of the increase in market work. Analysis of repeated cross-sections of time diary data from 1975 to 2004 shows that changes in "home production" account for at least half of the increase in market hours of work in response to policy changes. Data on expenditures from the Consumer Expenditure Survey from 1980 to 2003 show some evidence that expenditures on market goods likely to substitute for housework increase in response to a greater incentive to join the labor force. The baseline estimates imply that the elasticity of substitution between consumption of home and market goods is 2.43 . The results are consistent with the classic time allocation model of Becker (1965).
\end{abstract}

\author{
Alexander M. Gelber \\ The Wharton School \\ University of Pennsylvania \\ 1403 Steinberg-Dietrich Hall \\ 3620 Locust Walk \\ Philadelphia, PA 19104 \\ and NBER \\ agelber@nber.org \\ Joshua W. Mitchell \\ Department of Economics \\ Harvard University \\ Cambridge, MA 02138 \\ mitchel6@fas.harvard.edu
}


Hundreds of papers have investigated how incentives and policies affect hours worked. This paper examines how income taxes affect time allocation in the other two-thirds of the day, as well as market work. This promises to give us a richer understanding of how taxation affects the lives that people live.

We assess whether policy reforms induced single mothers to shift from one productive activity — work at home - to another-work in the market. Over the past thirty years, policymakers sought to increase the labor force participation of single mothers by expanding the Earned Income Tax Credit (EITC) and reforming the welfare system. One key motivation for reform was the perception that some single mothers were choosing to be idle and ought instead to contribute more productively to society by working (Robert Moffitt 2006). Phrased in efficiency terms, single mothers' leisure is considered by some to be the opposite of a "merit good," in the sense that it may be considered "intrinsically bad."

Understanding time allocation decisions is a core area of interest in labor economics. We interpret our results through the canonical model of time use of Gary S. Becker (1965). In this framework individuals derive utility from consumption of "commodities," each of which is produced using both a time input and a market goods input. Among other things, the model predicts that in response to a compensated wage increase, individuals' expenditures on market goods inputs rise relative to their time inputs into a given commodity. ${ }^{1}$ Using exogenous policy variation allows us to test this theory.

Estimating the impact of the tax rate on the distribution of non-market time allows us to examine several further issues of interest. We examine whether the observed trends in the data are due to policy changes or other trends across groups in the economy; address to what extent taxes, as opposed to other policy changes, were responsible for changes in time allocation; investigate whether taxes affect different components of non-market time differently or are neutral with respect to non-market time; and quantify the elasticity of the responses with respect to the tax rate. The estimation of elasticities, in turn, allows us to calculate the elasticity of substitution between home and market consumption. The analysis in the PSID also allows us to

\footnotetext{
${ }^{1}$ We discuss later the conditions under which this holds true.
} 
examine whether a fixed effect panel data model yields similar results to those obtained with the repeated cross sections of data that have typically been used. Compositional changes, such as the large increase in the share of single mothers in the population over our period, could bias results based on repeated cross sections.

Employed individuals take substantially less "leisure" time than the unemployed (Michael Burda and Daniel Hamermesh 2009), and we confirm in our data that the employed do only a bit less housework than the non-employed. It is perhaps surprising, then, that when we use tax policy to identify the estimates, the majority of the increase in market work is accounted for by decreases in housework. Using the Panel Study of Income Dynamics from 1975-2004, we find that among single women, labor force participation rises significantly when the fraction of their earnings taken away in taxes falls, consistent with findings in previous literature (Nada O. Eissa and Jeffrey B. Liebman 1996; Bruce D. Meyer and Dan T. Rosenbaum 2001). The baseline specification shows that when hours worked rise by 1 hour in response to lower taxes, time spent on housework falls by about 47 minutes. The finding that market work rises substantially and housework falls substantially in response to decreased taxation of labor earnings is robust to a wide variety of specification checks.

We supplement our examination of the PSID with an analysis of two additional datasets. $^{2}$ The repeated cross sections on time use assembled by Mark Aguiar and Erik Hurst (2007a) allow us to disaggregate non-market time into detailed categories. This analysis also shows that an increased net-of-tax share causes a substantial and significant increase in market hours worked and a decrease in housework. We investigate a variety of definitions of "home production" and "leisure" and find consistent evidence that the increase in market work corresponds to substantial and significant decreases in home production or non-market work. We also find some evidence that leisure decreases. The sum of time spent on eating, sleeping, and personal care, which is sometimes considered a separate category of interest, changes insignificantly. We examine a number of other disaggregated outcomes of interest. These

\footnotetext{
${ }^{2}$ The important work of Meyer and James X. Sullivan (2008) examines the time use and expenditures of single mothers in 1993 and 2003; Meyer and Sullivan (2004) examine expenditures of single mothers before and after several policy reforms.
} 
include time spent eating and preparing food, which decreases, and time spent sleeping - $\mathrm{a}$ hallmark of "idleness"-which changes insignificantly.

Analysis of the Consumer Expenditure Survey (CEX) allows us to investigate how these changes in market and home work interact with expenditure patterns. We find that expenditure on food prepared away from home - which could substitute for time spent on food preparationincreases in response to an increase in the incentive to participate in the labor force, whereas expenditure on food at home decreases significantly. In one specification, we find that overall food expenditure rises significantly, but food expenditure changes insignificantly in other specifications. In combination with the finding that time spent eating and preparing food falls, we interpret our results as evidence consistent with the Becker model.

Section 1 briefly reviews some of the major changes in tax policy impacting single women over the time period in question. Section 2 describes the data. Section 3 discusses our empirical specifications. Section 4 turns to the results from the PSID. Section 5 contains the results from the repeated cross-sections on time use. Section 6 describes results from the CEX. Section 7 concludes.

\section{Policy Environment}

During the period under consideration, a series of tax acts, passed in 1981, 1986, 1990, 1993, 2001 and 2003, dramatically changed the federal income tax code. We review the policies that affected single women the most. ${ }^{3}$ Among low-income taxpayers, the primary changes came from large expansions of the Earned Income Tax Credit (EITC), which increased the incentive to participate in the labor force. The size of the EITC, which is a refundable tax credit, depends on earned income and the number of qualifying children. The EITC tax schedule has three regions. Over the "phase-in" range, a percentage of earnings is transferred to individuals. Over the "plateau" region, an individual receives the maximum credit, after which the credit is phased out (currently at a rate of $21.06 \%$ ).

\footnotetext{
${ }^{3}$ See Rebecca M. Blank (2002), V. Joseph Hotz and John Karl Scholz (2003), Moffitt (2002), Moffitt (2003), Eissa and Hilary W. Hoynes (2005), and Meyer (2009) for reviews of the literature on welfare and the Earned Income Tax Credit.
} 
A small EITC was first introduced in 1975. The EITC was expanded substantially in the tax acts of 1986, 1990, and 1993. The 1986 expansion of the EITC increased the phase-in rate and region. These changes were reinforced by increases in the standard deduction and the dependent exemption to reduce income tax liabilities for tax filers at the bottom of the income distribution. The largest expansion of the EITC was in 1993. This reform increased the additional maximum benefit for taxpayers with two or more children, which reached $\$ 1400$ in 1996. The phase-in rate for the lowest-income recipients increased from $18.5 \%$ to $34 \%$ for families with one child and from $19.5 \%$ to $40 \%$ for families with two or more children. The tax act of 2001 reduced the bottom tax bracket rate from $15 \%$ to $10 \%$. Figure 1 summarizes important features of the changes in tax policy over this period for our PSID sample of single women. From the mid-1980s to the mid-to-late 1990s, the fraction of earnings a woman keeps if she participates in the labor force rose substantially for single women with children relative to those without children.

While we primarily focus on tax policy in this paper, it is worth noting changes in welfare policy, which we sometimes include as a control variable. Prior to 1997, Aid to Families with Dependent Children (AFDC) provided cash payments primarily to single mothers with children. The Food Stamp program gives low-income households coupons to purchase food. AFDC program parameters were set by the states. Most Food Stamp parameters are the same in all states, but because eligibility for Food Stamps and AFDC interact, people in similar situations in different states may receive different benefits under Food Stamps. Both of these programs had secularly growing expenditures until the mid-1990s. The typical effective tax rate imposed by the AFDC program was two-thirds. From 1980 through 1993, mean benefits for a working single mother remained roughly constant as implicit tax rates were reduced. Under AFDC, states could receive waivers to experiment with the parameters of their welfare programs. Between January 1993 and August 1996, the federal government approved welfare waivers in 43 states. Under waiver programs, states usually made welfare eligibility criteria more stringent and reduced the generosity of welfare benefits. In 1997, the Personal Responsibility and Work Opportunity Reconciliation Act replaced AFDC with Temporary Assistance to Needy Families (TANF), resulting in a wide variety of changes to the welfare system, including further cuts in average welfare benefits, work requirements, and more stringent time limits. 


\section{Data}

We use three datasets that are described more fully in our data appendix. Our core analysis uses the Panel Study of Income Dynamics. We use data from 1976-2005 on unmarried female heads of household aged 25-55 (inclusive), excluding cohabitators, who appear in at least two survey waves. ${ }^{4}$ We also exclude the PSID poverty sample and observations with allocated values of any outcome variables. We focus on single women for a number of reasons. First, many of the policies we examine were specifically oriented toward increasing the labor force participation of single mothers, providing fruitful exogenous variation. Second, it is difficult to measure the true average tax rate for married individuals: this can be done by assuming that one spouse takes the other spouse's earnings as given in making the labor supply decision, but there is evidence that this produces substantially biased estimates of labor supply parameters (Alexander M. Gelber 2009). Third, because married women's labor supply decisions interact with their husbands', their labor supply responses cannot be interpreted in terms of a canonical single-agent model such as Becker (1965). We have also run our regressions on a PSID sample of single male heads of household and find no evidence of a significant response to the policy parameters, consistent with existing literature on the labor supply of single men that typically finds little to no labor supply response to wages or taxes.

We measure labor force participation, usual weekly hours of market and home work, earned and unearned income, and demographics. Usual weekly hours worked includes hours worked at both main and extra jobs during the previous calendar year. We construct a binary variable measuring labor force participation equal to one if the respondent has positive usual hours worked and equal to zero otherwise. ${ }^{5}$ As our measure of housework, we use the answer to the following question: "About how much time do you spend on housework in an average week? I mean time spent cooking, cleaning, and doing other work around the house.” We use PSID data beginning in survey year 1976 because that is the first year this question was asked. For further details about the construction of our dependent variables, please refer to the Data Appendix. All observations are weighted by the PSID cross-sectional weights.

\footnotetext{
${ }^{4}$ Survey years 1976-2005 contain data on activities in the previous year, i.e. data on years 1975-2004.

${ }^{5}$ In Appendix Table 1 we show that our main results are robust to alternative measures of hours worked and labor force participation.
} 
The sample includes 9,242 observations, corresponding to 1,243 individuals. Summary statistics for the primary variables of interest are in Table 1. It is notable that individuals in the sample work nearly a full workweek ( 37.50 hours) on average. $89 \%$ of the sample works a positive number of hours during the year. For a comparison with the CPS, please see the Data Appendix. Figure 2 shows the trends over time in mean market work and housework among single women with and without children, using PSID data. Over the period of the primary policy changes, from the mid-1980s to the mid-to-late 1990s, mean hours worked rose markedly for single women with children relative to those without children. In other time periods, little relative change is seen over time in the two groups. The trends in housework in the two groups look almost like a mirror image of the trends in market work. Housework fell substantially for single women with children relative to those without during the period of the primary policy changes, and the relative change in housework in the two groups is over half as large as the relative change in market work.

Our more detailed time use data use come primarily from the repeated cross sections assembled by Aguiar and Hurst (2007a), henceforth AH. ${ }^{6}$ The reader can review their paper for a detailed description of the data. AH use data from 1965, 1975, 1985, 1992-4 (referred to as "1993" for concision), and 2003. AH code time use categories as consistently as possible across cross sections. We make the following changes relative to the AH data. We use data from 19752004 and restrict the sample to unmarried female heads of household aged 25-55 (inclusive). We exclude the 1965 cross section since it is unrepresentative of the country (with no sample weights to make it representative), and since it is outside of the time frame we consider in our analysis of the PSID and CEX. For the 1993 cross-section, number of children is missing, though a variable measuring the presence of a child is not missing. As a result, we impute it by assuming that everyone with at least one child has exactly two children. ${ }^{7}$ The $2003 \mathrm{AH}$ data come from the American Time Use Survey (ATUS), and we supplement the 2003 data with data from the 2004 ATUS cross-section to increase sample size and match exactly the final labor market year in the PSID.

\footnotetext{
${ }^{6}$ Books on time use include Becker and Gilbert Ghez (1975), Thomas Juster and Frank Stafford (1985), John Robinson and Geoffrey Godbey (1999), and Hamermesh and G.A. Pfann (2005). Valerie Ramey (2008) critiques some aspects of the AH definition of leisure; AH (2008) respond.

${ }^{7}$ The results are not sensitive to other imputation strategies.
} 
We follow AH in defining several alternative measures of leisure and home production. Leisure 1 consists of activities broadly relating to socializing, relaxing, and enjoyment of life. Leisure 2 includes all of the activities in Leisure 1, plus eating, sleeping, and personal care. Leisure 3 includes all of the activities in Leisure 2, plus child care. AH define Home Production as preparing meals, housework, and gardening and pet care. They define Non-Market Work as Home Production plus time spent obtaining goods and services. Summary statistics from the time use data are displayed in Table 1. The time use data cover only selected years during the period 1975-2004, so it is unsurprising to find some minor differences in the summary statistics. There are two notable differences between the PSID and the time diary data. Market hours of work are lower in the time diary data than in the PSID, consistent with the standard finding that time use data show lower hours worked than the PSID or Current Population Survey (Aguiar and Hurst 2007a). Mean hours of housework is substantially lower in the time diary data; as noted by John Knowles (2005) and confirmed in our data, housework in the PSID corresponds much more closely to "home production" in the time diary data.

We use data from the CEX interview sample from 1980-2003 on unmarried female heads of household aged 25-55 (inclusive). We use the raw CEX data produced by the Bureau of Labor Statistics measuring expenditures on various disaggregated expenditure categories of interest, such as expenditures on domestic service, major appliances, and food, as well as demographics including state of residence and number of children. As in Kerwin Charles, Hurst, and Nikolai Roussanov (2009), we collapse the quarterly CEX data to the yearly level as described in the Appendix. Summary statistics for the CEX are shown in Table 1. Demographics are within the range expected from the PSID, given the differing sampling methods and time periods covered. Mean yearly expenditures on food are $\$ 2,847$, and $\$ 2,123$ is spent on food at home.

\section{Empirical Specifications}

In our basic empirical specification in the PSID, we perform an OLS regression of usual weekly hours of time spent on an activity (market work, housework, or other time) for individual $i$ in year $t$ on the average net-of-tax share (1- $\tau)$, a measure of unearned income $Y$, a set of 
demographic control variables $X$, year fixed effects $\theta$, individual fixed effects $\Gamma$, and an error term $\varepsilon$ :

$$
h_{i t}=\beta_{1}\left(1-\tau_{i t}\right)+\beta_{2} Y_{i t}+X_{i t} \beta+\theta_{t}+\Gamma_{i}+\varepsilon_{i t}
$$

The effective average net-of-tax share is in turn defined as the fraction of an individual's earnings that she would keep, if she chose to work:

$$
\left(1-\tau_{i t}\right)=\left[E_{i t}-\left(T_{w, i t}-T_{n w, i t}\right)\right] / E_{i t}
$$

where $E$ is earnings if you work, $T_{w}$ is net taxes paid if you work, and $T_{n w}$ is net taxes paid if you do not work. This measures an individual's incentive to participate in the labor force and is relevant if an individual makes a choice between staying out of the labor force and participating in the labor force and earning the pre-tax amount $E$. This may be the relevant choice if individuals face fixed costs of work or a discrete menu of options of numbers of hours to work. ${ }^{8}$

Since earnings-if-work $E$ is unobserved, we impute $E$ by performing a regression of actual annual earnings on demographic variables, year effects, and an error term: ${ }^{9}$

$$
\ln \left(E_{i t}\right)=X_{i t} \beta+\theta_{t}+\varepsilon_{i t}
$$

The demographics included are a full set of dummies representing all possible values of age, education, and number of children. Since earnings are approximately lognormally distributed, we log earnings before including it in the regression; similar but slightly less precise results are obtained when we use a linear regression to impute earnings. So that zeroes of the dependent variable can be included in the regression, we add 10 to all values of earnings before logging. ${ }^{10}$ We obtain very similar results with other choices, such as adding 1 or 100 to all values of earnings before logging. We then form a measure of imputed earnings for each individual in each year using the coefficients estimated from this regression. Earnings are imputed for those with both positive earnings (whose actual earnings could be endogenous) and for those with zero earnings (whose earnings if they worked are unobserved). This imputation strategy bears

\footnotetext{
${ }^{8}$ Previous work has found a strong extensive margin response to tax incentives for single mothers but no evidence of an intensive margin response (see the surveys cited above). Consistent with these findings, when we include both the average and marginal tax rate in our regressions, the coefficient on the marginal tax rate is small and insignificant, and the coefficient on the average tax rate is large, highly significant, and very similar to the coefficient estimates in the main specifications. Our specification above omits the wage because wages are not observed for women who do not work. We later address this by including a measure of the wage in several specifications.

${ }^{9}$ We address self-selection into the labor force in several specifications discussed later.

${ }^{10}$ When we exclude zeroes of earnings from the income imputation, we obtain very similar but slightly less precise results.
} 
similarities to the strategies in Meyer and Rosenbaum (2001) and Francine D. Blau and Lawrence M. Kahn (2007).

Using imputed earnings $E_{i t}$ for each individual in each year, we then construct simulated average and marginal tax rates using the Taxsim program of the National Bureau of Economic Research (Daniel Feenberg and Elizabeth Coutts 1993). We include federal and state income and payroll taxes. ${ }^{11}$ For calculating welfare benefits, we use earnings to construct the value of food stamp and AFDC/TANF benefits if the individual does and does not work. These are constructed using the information on food stamp and AFDC/TANF generosity at different income levels in the Urban Institute's TRIM3 database. For constructing these, we incorporate the same information as Meyer and Rosenbaum (2001). Since all versions of (1) include individual fixed effects, as well as controls for (at a minimum) the same demographic variables that appear in the imputation regression (2), identifying variation in constructed tax rates in (1) will derive from variation across individuals and time in national and state policy changes. We also investigate a substantial number of variants of (1), described more fully in our results section. It is worth noting that estimates of the response to taxation in a panel must address mean reversion in income (Moffitt and Mark O. Wilhelm 2000; Jonathan Gruber and Emmaneul Saez 2002). As Moffitt and Wilhelm (2000) note, this imputation procedure avoids the problem of mean reversion.

In the repeated cross sections of data from the CEX, we impute tax rates in the same way, and our basic specification is the same as (1) but lacks individual fixed effects:

$$
h_{i t}=\beta_{1}\left(1-\tau_{i t}\right)+\beta_{2} Y_{i t}+X_{i t} \beta+\theta_{t}+\varepsilon_{i t}
$$

In the repeated cross sections of data on time use, our specification is the same as (3), but we lack a consistent measure of unearned income and omit this from the regression:

$$
h_{i t}=\beta_{1}\left(1-\tau_{i t}\right)+X_{i t} \beta+\theta_{t}+\varepsilon_{i t}
$$

To hold the method constant across datasets, we use the vector of coefficients from the PSID to impute earnings and simulated tax rates in the time use and CEX data.

\section{Limitations}

\footnotetext{
${ }^{11}$ Following Meyer and Rosenbaum (2001), we do not use capital income in constructing marginal tax rates. The results are not sensitive to this choice.
} 
This basic strategy has a number of limitations, some of which are addressed in detail in the results section. It is important to note two remaining issues. First, the labor supply specification we consider can be derived from a model of utility maximization in a static context (Richard Blundell and Thomas MaCurdy 1999). This can be interpreted in a dynamic context only in the presence of myopia or constrained capital markets. We interpret our findings on consumption in terms of a static Becker model of consumption and time allocation, but we acknowledge that this interpretation is less clear in a dynamic model in which consumption and labor supply decisions are made jointly. ${ }^{12}$ Second, individuals who go from single to married are excluded from the sample, and those who choose to divorce are included in the sample. These choices could themselves be influenced by policy variation (see Meyer 2009 for a survey). James Alm and Leslie Whittington (1995) find substantial responses to the additional tax liability a couple faces from the decision to get married rather than stay single among cohabitators, who are excluded from our sample, and little evidence of responses among other groups.

\section{Results: Panel Study of Income Dynamics}

The main PSID results are in Table 2, organized into four panels. Panel A shows results from the PSID with a dummy for labor force participation as the outcome and a linear probability model; Panel B shows usual hours worked as the outcome; Panel C shows usual hours of housework as the outcome; and Panel D shows residual (non-housework, non-market work) time as the outcome. ${ }^{13}$

\section{Basic Estimates}

Column 1 of Table 2 shows the results with the basic specification, including individual and year fixed effects, as well as a full set of dummies representing all possible values of age and number of children. The effect on labor force participation in Panel A is strong and precisely estimated. The implied elasticity of participation with respect to the net-of-tax share is .43, which falls within the existing range of estimates (.35 to 1.7, with a central elasticity of .7; see

\footnotetext{
${ }^{12}$ In a two-stage budgeting framework, controlling for consumption-based income will yield an estimate of the effect of anticipated wage changes on labor supply. We controlled for food expenditure plus labor earnings as a proxy for consumption-based income (and also experimented with imputing overall consumption using food consumption). The coefficient on the net-of-tax share is always within $20 \%$ of the specifications shown in the tables, with a similar standard error. When we instrument for food expenditure plus labor earnings using the welfare benefits a woman would receive if she did not work (controlling separately for the welfare average tax rate), the point estimate of the effect of the wage is usually similar but the standard error increases somewhat.

${ }^{13}$ The point estimates of the effect of the net-of-tax share on hours worked, housework, and other time always add to zero, consistent with the requirement of the time budget constraint.
} 
Eissa, Henrik Kleven, and Claus Kreiner 2008). Column 1 of Panel B likewise shows a strong and highly significant effect on usual hours worked, with an elasticity of .43. Column 1 of Panel $\mathrm{C}$ shows that this corresponds to a strong negative effect of the net-of-tax share on usual hours of housework. The coefficient on the net-of-tax share variable (-14.65) is $78 \%$ as large as the coefficient (18.87) when hours worked was the dependent variable in Panel A Column 1, suggesting that most of the increase in hours worked is accounted for by decreases in time spent on housework. Column 1 of Panel D shows a smaller and insignificant decrease in other time, with a corresponding coefficient of $-4.21 .^{14}$ The coefficient on the net-of-tax share when housework is the dependent variable is significantly more negative than the coefficient on the net-of-tax share when other time is the dependent variable $(\mathrm{p}<.01){ }^{15}$

\section{Specification Checks}

We now turn to various specification checks. Throughout all of these robustness checks, the same pattern of results will hold: a strong positive effect of the net-of-tax share on market work, a negative effect on housework that accounts for around half or more of the increase in market work - with a central estimate of this fraction around two-thirds - and a negative and insignificant effect on other time. Column 2 of Table 2 addresses the possibility of self-selection. We perform a Heckman selection correction and add the inverse Mills ratio to the right-handside of the imputation regression (2). ${ }^{16}$ We identify the selection term by calculating the average net-of-tax share that an individual with their true number of children and with average income (over all individuals in the sample) would face in a given year. We add this tax rate to the first stage predicting labor force participation but omit it from the second stage. We then estimate (2) and compute imputed incomes for each individual, on the basis of which we calculate imputed net-of-tax shares using the method described in Section 3. Column 2 shows results using the

\footnotetext{
${ }^{14}$ When we remove individual fixed effects from the regressions and treat the data as repeated cross sections, we obtain highly significant results with coefficients that are usually around 65 to $70 \%$ of the size of the estimates with fixed effects. See the data appendix for further discussion.

${ }^{15} \mathrm{We}$ consider the baseline estimates to be a central specification for a number of reasons. The baseline specification includes the longest possible time period, does not include many controls (leading to efficiency and precision), and generates broadly similar results to all other specifications except two: controlling for extra fixed effects (Column 9 of Table 2) and the IV for the average net-of-tax share (Column 6 of Table 2). Controlling for extra fixed effects involves a substantial efficiency loss because of the hundreds of extra independent variables; the coefficient estimates are correspondingly less precise. The IV for the net-of-tax share could be considered a second central specification but cannot be performed in the time use and expenditure results because they are not panel datasets and therefore lack a measure of a person's average income over several years.

${ }^{16}$ This is similar to the imputation in Eissa and Hoynes (2004).
} 
selection-corrected average tax rate, which yields similar results to Column 1, with somewhat larger point estimates.

Column 3 adds to the regression a measure of the incentives created by transfer programs. We control for the "welfare average tax rate," defined as welfare transfers if an individual works minus welfare transfers if an individual does not work, as a fraction of imputed earnings. "Welfare" includes both food stamps and AFDC/TANF transfers. ${ }^{17}$ The coefficient on the net-of-tax share is nearly unchanged from Column 1. Welfare benefits do not have a significant effect on labor supply or home production, though the standard error does not rule out a substantial effect. Column 4 limits the sample to the period prior to 1993, when state welfare waivers were first implemented, in order to isolate tax variation from variation in welfare program parameters other than monetary benefits. We again find a similarly-sized and significant effect on housework but a larger point estimate of the effect on market work and other time.

In Column 5, we recognize that non-labor income is not exogenously determined and instrument for it using the size of welfare benefits that a woman would receive if she did not work. We recognize that welfare benefits have both price and income effects on labor supply, and so we also control separately for the welfare average tax rate from Column 3. A limitation of this approach is that the welfare average tax rate is separately identified from the instrument, welfare benefits if an individual does not work, solely off functional form. This must be traded off against the gain of a plausibly exogenous source of variation in non-labor income. The results are again similar to those in Column 1, with a slightly larger fraction of the change in market work accounted for by the change in housework. While the welfare average tax rate has only a small impact on labor supply and other time use outcomes, it is important to note that the point estimate of the coefficient on non-labor income implies that increases in welfare benefits have a substantial negative income effect on labor supply.

In Column 6, we address the fact that our measure of the average net-of-tax share is a noisy measure of the true fraction of earnings taken away from a given individual, both because

\footnotetext{
${ }^{17}$ Meyer and Rosenbaum (2001) find no evidence for an effect of Medicaid benefits on labor supply.
} 
our imputation may not measure the true earnings potential of any given individual, and because we do not have administrative data on variables such as taxable income and number of dependents. To address measurement error, we form a second measure of the average net-of-tax share that an individual faces. Our second measure of the average net-of-tax share is calculated using an individual's average labor income over the full sample period. In a given year, we calculate the average net-of-tax share that each woman would face given that she earned her average labor income over the full sample period and faced the true tax schedule in that year. We then instrument for this measure of the average net-of-tax share using the measure based on imputed earnings that we have used in Columns 1 and 3-5. This makes a large difference to the estimated coefficients, more than doubling them relative to Column 1, and moving the implied elasticity of participation a bit above the midpoint of elasticities previously estimated in the literature. The larger coefficient estimates suggest that, in fact, measurement error may be leading to attenuation bias in other specifications. It is important to note that the central conclusion that we take away from the tables - that at least half of the increase in market work came from housework-still holds.

Column 7 instruments for the net-of-tax wage using the net-of-tax rate. Since wages are not observed for those who do not work, we impute wages using demographics. We perform regression (2) for labor force participants with the hourly wage rate as the dependent variable, where the hourly wage rate is constructed by dividing yearly earnings by yearly hours worked. The endogenous variable is then the imputed wage rate multiplied by the net-of-tax rate constructed using average earnings as in Column 6. As in Column 6, the instrument is the netof-tax rate constructed using earnings imputed with demographics. ${ }^{18}$ The coefficient on the netof-tax wage represents the effect on hours worked or hours of housework of a $\$ 1$ increase in the net-of-tax wage. While they are scaled differently, the results in Column 7 are similar to those we have found previously, both in terms of the estimated elasticities and in the sense that most of the increase in hours worked is accounted for by the change in hours of housework, with an insignificant effect on residual time.

\footnotetext{
${ }^{18}$ Note that division bias should not affect the results, both because we use the imputed (rather than actual) wage, and because the instrument is not affected by division bias.
} 
In our later discussion of our results, we interpret an increase in the net-of-tax rate as representing an increase in the net-of-tax wage. Single women with and without children respond similarly to economic shocks such as changes in the unemployment rate. ${ }^{19}$ It is therefore reasonable that demand shocks to the two groups changed their wages in similar ways. Because they are competing in similar labor markets, it is unlikely that the incidence of the policy changes on the pre-tax wage was different in the two groups. As a piece of evidence that the pre-tax wage was not positively correlated with the net-of-tax share (due to tax incidence or demand shocks), we regressed pre-tax hourly wages of labor market participants on the imputed net-of-tax share, plus age, number of child, and year fixed effects, and found a small and insignificant negative coefficient on the imputed net-of-tax share.

To investigate further the responsiveness of hours worked with respect to the net-of-tax wage, we ran a selection-corrected Tobit. Following the procedure suggested in Wooldridge (2002), we first ran a Tobit of hours worked on the actual net-of-tax hourly wage rate and the basic control variables (omitting individual fixed effects and treating the data as repeated cross sections); for observations with positive hours, we obtained the Tobit residuals; for observations with positive hours, we regressed the net-of-tax hourly wage on the basic control variables, the Tobit residuals, and the average net-of-tax share computed using an individual's actual number of children and the average income over all years in the full sample (the last of which provides the identifying variation); obtained the fitted values; and finally ran a Tobit of hours worked on the basic controls (omitting individual fixed effects) and the fitted values. This effectively constitutes an entirely different way of assigning net-of-tax wages to non-participants, than our imputation procedure for assigning tax rates in the main specification; the method for assigning the net-of-tax rate here is the standard selection correction technique. The estimated elasticity of hours worked with respect to the net-of-tax wage, computed at the mean, is .37 (with a standard error of .16). This is remarkably similar to our baseline elasticity of .43.

Column 8 controls for various other factors that could impact labor force and housework activity: the minimum wage in the state, state GDP, the presence of a welfare waiver, average labor income for an individual over the full sample period interacted with year, and education-

\footnotetext{
${ }^{19}$ Meyer and Rosenbaum (2001) discuss the validity of this control group in detail.
} 
by-year fixed effects. We used five education groups: no high school diploma, high school diploma, some college, college graduate, and post- graduate. The interaction of education group with year fixed effects controls for demand shocks potentially arising from sources such as skillbiased technological change. We also tried including a dummy for whether states had a time limit for welfare receipt, which is highly correlated with the waiver variable and made little difference to the results. The results are remarkably similar to the basic set of results in Column 1 .

Column 9 adds a very stringent set of controls: number-of-child-by-year fixed effects (interacting dummies for all possible numbers of children with dummies for each year), state-byyear fixed effects, and number-of-child-by-state fixed effects. All told, the regression has well over 1,000 dummy variables. Despite all of these controls, the results still show a significant positive impact of the net-of-tax share on labor force participation and a significant negative impact on housework (as well as a significant positive impact on yearly hours worked, which is not shown). The coefficients fall substantially relative to Column 1, but as before, the effect of taxes on hours of housework is greater than half of the effect of taxes on hours of market work. This is particularly noteworthy since the number-of-child-by-year fixed effects take out all of the variation displayed in Figures 1 and 2. In other words, we know that usual hours worked increased substantially for single women with children relative to single women without children over the sample period, and that the net-of-tax share rose for single women with children relative to single women without children over this period. By putting in number-of-child-by-year fixed effects, we investigate whether other sources of variation also drive increased hours worked and decreased housework. As shown in Figure 3, the net-of-tax share rose much more for lowincome women with children than for higher-income women with children. ${ }^{20}$ The figure shows that, correspondingly, the change in market work was substantially more positive, and the change in housework substantially more negative but smaller in absolute value than the change in market work, for high-income women with children than for low-income women with children.

We also performed other robustness checks. We performed the earnings imputation instead by matching labor market participants and non-participants through a propensity score

\footnotetext{
${ }^{20}$ Education and age appear in our imputation regression and drive substantial variation in imputed income.
} 
(calculated through a logistic regression of a labor force participation dummy on dummies for age, education, number of children, race, and year). We then replaced the net-of-tax share of a non-participant with the net-of-tax share of the participant to which she was matched and used this as our measure of the non-participant's net-of-tax share. To take account of higher moments of the distribution of average tax rates conditional on demographics - rather than only the mean - we performed quantile regressions of earnings on our demographic variables for the $10^{\text {th }}$, $20^{\text {th }}, 30^{\text {th }} \ldots 90^{\text {th }}, 99^{\text {th }}$ quantile of the earnings distribution. We then imputed income at each of these quantiles, calculated the implied average net-of-tax share at each quantile, and for each individual in each year averaged together the implied net-of-tax shares over all quantiles. We then used this measure of the average net-of-tax share in (1). We obtained similar results to the baseline specification, less precise but still highly significant. We also experimented with various combinations of the specifications in Columns 1-9. To address the possibility that an individual's number of children could be endogenous to tax policy, we calculated the maximum number of children that an individual has over the full sample period, rather than using the actual number of children that the individual has at a given point in time, and use this (maximum) number of children to calculate the net-of-tax share in each year. We also tried controlling for state welfare waivers and their interaction with number of children. We removed individuals who are living with adult relatives (who might also be doing housework). Through all of these specifications, we continued to obtain similar results. Finally, we used the log of the net-of-tax share (or the log of the net-of-tax wage in the relevant specifications), rather than entering it linearly, and estimated similar elasticities.

In Column 1 of Appendix Table 1, we show the results when yearly hours of market work is the dependent variable. Putting the coefficient on the average net-of-tax rate (839.17) in weekly terms by dividing by 52 yields an estimated a weekly increase of 16.14 , which is similar to the coefficient estimate (18.87) in the baseline specficiation. We defined labor force participation as positive usual weekly hours of work, in order to be consistent with the definition of our hours worked variable. In Column 2 of Appendix Table 1, we instead define labor force participation as "currently working" and obtain similar results. In Column 3, we define labor force participation as positive hours of work over the course of the year and again obtain similar results. 


\section{Heterogeneity Analysis}

Table 3 shows an analysis of the heterogeneity of the effects across population groups. Individuals under 40 show a larger reaction to the net-of-tax share than those over 40 . We split the sample into women with and without children. The labor supply elasticity is substantially higher in the group without children. Interestingly, for women with children, the point estimates show that nearly all of the increase in market work is accounted for by decreases in housework, whereas for women without children, most of the increase in market work is accounted for by decreases in residual time. Since we obtain significant hours worked responses when we run the regression on each of these groups separately, this again demonstrates that our results rely on more variation than the comparison over time of outcomes and tax rates among single women with and without children. In results not shown, we split the sample into halves by imputed income, in order to assess whether the policy changes tended to affect those expected to be in lower or higher income ranges. The point estimates suggest that among lower-income individuals, housework responds to taxation more than among higher-income individuals (similar to the results in Meyer and Sullivan 2008).

\section{Correlations between Housework and Market Work}

To investigate how market work and housework relate in the summary statistics, we regressed usual hours of market work on a dummy for participating in the labor force, individual fixed effects, year fixed effects, and the controls from our basic specification; in a second regression, we performed this regression but with usual hours of housework as the dependent variable; and in a third regression, we performed this regression but with residual time as the dependent variable. The results are shown in Columns 4 through 6 of Appendix Table 1. When individuals participate in the labor force, the decrease in their housework time accounts for only a small fraction of the increase in their hours of market work. We obtain very similar results when we omit individual fixed effects.

This finding is noteworthy for two reasons. First, this is the opposite result from what we obtain using variation coming from policy changes, highlighting the important role that these changes play in identifying the results. A potential reason for the divergence is unobserved heterogeneity: individuals who do larger amounts of market work also tend to do larger amounts of housework. It is likely that in a cross-section, employed individuals have substantially 
different tastes for market work and leisure than individuals who are not employed. The results in Columns 4 to 6, furthermore, are quite similar when we do and do not include individual fixed effects. This leads us to believe that the fixed effects estimates in Columns 4 to 6 are also strongly driven by (time-varying) unobserved heterogeneity. Second, one possible objection to the main results of the paper is that individuals could inaccurately report a roughly constant sum of housework and market work, perhaps because they feel they ought not admit that they do little work in either the market or the home. Column 5 shows that reported housework is only slightly lower among labor force participants than among non-participants, so such a story cannot explain our main results.

\section{Results: Time Use Data}

We next examine in greater detail the effect of taxes on time use using the repeated cross sections of time diary data assembled by AH (2007a). The basic results are shown in Table 4. Columns 1 and 2 show that as in the PSID, labor force participation and hours of market work rise significantly in response to an increase in the net-of-tax share. The coefficient on the net-oftax share is somewhat higher than the basic specification in Column 1, Panel B of Table 2, but the results are well within the range estimated in the PSID. Column 3 shows that housework falls in response to an increase in the incentive to participate in the labor force. The point estimate of the fall in housework is insignificantly smaller than in the PSID, which is unsurprising since mean hours of housework is lower in the time diary data. Similarly, the broader AH measure of "Home Production" falls substantially and significantly, with a coefficient over half the size of the coefficient in Column 2. The effect on "Non-Market Work," equal to Home Production plus time spent obtaining goods and services, is similarly sized and significantly different from zero. Columns 6 through 8 show the effect on AH's various measures of leisure, Leisure 1 through Leisure 3. The estimated effect on leisure is always negative but is only marginally significant for Leisure 2 . We cannot reject at conventional significance levels that the effect on home production is different than the effect on any of the measures of leisure.

Columns 9 through 12 show other outcomes of interest. Time spent preparing and eating meals falls significantly, with a coefficient of substantial size. Interestingly, time spent with children increases insignificantly, with a standard error that rules out a large decrease in time 
spent with children. To the extent that this regression is identified off the comparison over time of women with and without children, this result must be interpreted with caution because women without children spend little time with children. To address this concern, we estimated the regression only for women with children. This regression also showed no evidence that child care decreased significantly: with a sample size of 2,108, the coefficient on the net-of-tax share was -1.61 , and the standard error was 9.92. "Hard-working" individuals are often thought to sleep less than "lazy" individuals. In light of the view of some that "idle" single mothers need motivation from policy to "work harder," it is noteworthy that sleep is insignificantly changed by an increase in the net-of-tax share. ${ }^{21}$ Finally, eating, sleeping, and personal care are sometimes considered together as a "tertiary" category alongside home production and leisure (e.g. Burda, Hamermesh and Philippe Weil 2008). Column 12 shows that this category falls insignificantly.

\section{Results: Expenditure Data}

Table 5 shows results using expenditure data. ${ }^{22}$ Since time spent preparing and eating food fell in response to an increased incentive to participate in the labor force, it is of interest to test how expenditures on food changed. ${ }^{23}$ In Column 1 of Table 5, we use PSID data on food expenditures and find a substantial positive but insignificant effect of the net-of-tax share on food expenditures. Columns 2 through 7 rely on data from the Consumer Expenditure Survey. Column 2 shows that food expenditures have a small negative and insignificant response to an increased net-of-tax share. We next break down food expenditures into their component parts: food at home (primarily food purchased at grocery stores), food away from home (primarily food purchased from restaurants), and food at work. Column 3 shows that food away from homewhich seems the most likely to substitute for time spent preparing food-rises significantly. Food at home falls significantly, while food at work rises significantly (Columns 4 and 5). We investigate expenditures on domestic services and major appliances in Columns 6 and 7, since these seem most likely to be substitutable with home time. ${ }^{24}$ The point estimates indicate that both rise, although the coefficients are insignificant. Overall, a reasonable conclusion from the data on expenditures is that they usually respond in the expected directions, but that the sample

\footnotetext{
${ }^{21}$ Jeff E. Biddle and Hamermesh (1990) explore the relationship between market work and sleep.

${ }^{22}$ When we run regressions in the Consumer Expenditure Survey of hours worked or labor force participation on the net-of-tax rate, analogous to those we ran in the PSID and time diary settings, we obtain similar results to those shown in Tables 2 through 4.

${ }^{23}$ Thomas DeLeire and Helen Levy (2005) examine food expenditures by single mothers.

${ }^{24}$ The estimated effect on child care expenditures is very similar to the effect on expenditures on domestic services.
} 
size is usually not large enough to detect significant responses and that there should correspondingly large uncertainty about the true magnitude of the effects.

\section{Comparison with the Becker Model}

The rise (or insignificant response) of food expenditures, in combination with the decrease in the time use data on time spent preparing and eating food, can be seen as consistent with the Becker model. ${ }^{25}$ In the Becker model, individuals derive utility $U\left(Z_{1}, Z_{2}, \ldots Z_{m}\right)$ from consumption of commodities $Z_{1}, Z_{2}, \ldots Z_{m}$. Each of the $Z_{i}$, in turn, is produced using goods $x_{i}$ and time $T_{i}: Z_{i}=f_{i}\left(x_{i}, T_{i}\right)$. This utility function is maximized subject to the time constraint $\left(T_{1}+\ldots T_{m}+T_{w}=T\right.$, where $T$ is the time endowment and $T_{w}$ is the time spent on market work) and the budget constraint $\left(p_{1} x_{1}+\ldots p_{m} x_{m}=V+T_{w} w\right.$, where $p_{i}$ are prices, $w$ is the wage, and $V$ is unearned income). We consider the version of the Becker model in which substitution between goods and time is possible in producing a commodity (i.e. production of the commodity is not Leontief in goods and time). As Becker (1965) notes, for a given amount of a commodityholding $Z_{i}$ constant - a compensated wage increase will cause $x_{i} / T_{i}$ to rise. If the wage change causes substitution across commodities, then it is possible that the associated change in the level of $Z_{i}$ could cause a fall in goods relative to time, if $f$ is not homothetic and this effect of the scale of $Z_{i}$ on the ratio of goods to time is large enough to overwhelm the substitution effect between goods and time holding $Z_{i}$ constant. In the leading case of a homothetic production function $f$, the ratio of time to goods is invariant to the scale of $Z_{i}$, and so it is unambiguously the case that a compensated wage increase causes a rise in goods relative to time: $\left.{ }^{26,27} \frac{d\left(x_{i} / T_{i}\right)}{d w}\right|_{u}>0$.

We observe $p_{i} x_{i}$ in the data, but in a competitive market, $p_{i}$ should be the same in our treatment and control groups. Thus, if we observe that $p_{i} x_{i} / T_{i}$ rises, we interpret this as an

\footnotetext{
${ }^{25}$ See Hamermesh (2008) on the substitutability of goods and time in producing consumption of food.

${ }^{26}$ This more generally holds when the effect of the scale of $Z_{i}$ does not cause goods to fall too much relative to time.

27 The Becker model prediction is about the time and market goods responses to a compensated wage change. Policy-induced changes in labor supply and other time use outcomes along the extensive margin are typically considered compensated changes (see e.g. Eissa, Kleven, and Kreiner 2004). It is nonetheless worth noting that we investigated the effect of unearned income on time spent eating and preparing food in the 2003 ATUS cross section (since most time use cross sections lack a measure of unearned income). We found a positive and insignificant effect of unearned income, with a coefficient of .00000007 and a standard error of .0000008 , which would imply that income effects are very small. We then calculated the compensated elasticity of food expenditures, using the income effect implied by the coefficient on capital income as a measure of the income effect, and found that the compensated elasticity is insignificantly different from zero in both the PSID and Consumer Expenditure Survey. These findings are therefore likewise supportive of the Becker model.
} 
increase in $x_{i} / T_{i}$. Expenditures on the market input (food bought in the market) should rise relative to the time input (time spent preparing and eating food) into a commodity (food consumption). ${ }^{28}$ If the initial level of $x_{i}$ differs across the treatment and comparison groups, then an equal change in the price level for each group should cause a larger response of expenditures in the group with the larger initial level of $x_{i}$. To address this issue, we estimate the response of $\log$ food expenditures to the net-of-tax rate in Appendix Table 2. Importantly, we find that log food expenditures in the PSID rise significantly in response to an increase in the net-of-tax rate, which is stronger evidence in favor of the Becker framework. ${ }^{29}$

\section{Conclusion}

We examine how income taxes affect time allocation. We find that when individuals keep a greater fraction of their earnings when participating in the labor force, they work substantially more: the baseline estimates show that the elasticity of hours worked with respect to the average net-of-tax share is .43 . This represents one of the first examinations of the effect of tax incentives on hours worked using panel data and individual fixed effects. We find that this corresponds to a substantial and significant decrease in housework: across our specifications, the point estimates center around showing that two-thirds of the increase in hours worked corresponds to a decrease in housework. These results are robust to a wide variety of specification checks in the PSID and also hold in repeated cross sections of data on time use. In the repeated cross-sections of data, we find a bit of evidence that "leisure" time decreases significantly in response to an increase in the incentive to join the labor force. We also find some evidence that expenditures on goods that appear substitutable with housework increase in response to an increased incentive to enter the labor force.

Our results have implications for several areas of economic inquiry. The finding that the increase in market work corresponds largely to a decrease in housework suggests that public policies affecting labor force incentives largely shift people from one productive activity to another. In light of the fact that the policy reforms pursued over the period in question were

\footnotetext{
${ }^{28}$ The Becker model also predicts that as the net-of-tax wage increases, individuals' consumption of earningsintensive commodities should fall relative to consumption of less earnings-intensive commodities. However, we do not directly observe the relative earnings intensities of different commodities.

${ }^{29}$ We do not estimate the response of the log of other expenditure categories to the tax rate because they are often equal to zero, whereas food expenditures are rarely equal to zero. Adding 1 or 10 or 100 to the dependent variable before logging it yields similar results to those shown in Appendix Table 2.
} 
motivated in part by decreasing the "unproductive" activity of "idle" single mothers, it is notable that the policies in fact mainly shifted individuals from work at home to work in the market. Externalities or internalities from time use decisions would lead to efficiency consequences of the housework and other time outcomes examined. The results suggest that taxes are not neutral with respect to non-market time, as housework changes more than other non-market time.

When the net-of-tax rate rises, implying that the net-of-tax wage rises, food expenditures rise significantly or change insignificantly, but the fall in the time spent preparing and eating food is substantial and (marginally) significant. Collectively, we interpret this evidence as consistent with the classic Becker (1965) model. The results in the time use data are consistent with the model of Reuben Gronau (1977), which, in the presence of homothetic preferences and fixed costs of work, predicts a decrease in both home production and leisure in response to entry into the labor force induced by a decrease in the tax rate.

Our results are perhaps surprising in view of the Burda and Hamermesh (2009) finding that employed individuals enjoy substantially less leisure time, and only a bit less home production time, than the unemployed, which is similar to the regression results in our Appendix Table $1 .{ }^{30}$ Our findings are supportive of the literature in macroeconomics, spawned by Jess Benhabib, Richard Rogerson, and Randall Wright (1991), that explains the magnitude of business cycle fluctuations in part through substitutability between market and home goods. Following their analysis, if utility is defined as

$$
U_{i}=\ln \left[a_{i} c_{m i}^{e}+\left(1-a_{i}\right) c_{n i}^{e}\right]+v_{i}\left(1-h_{m i}-h_{n i}\right)
$$

where $c_{m i}$ is consumption of market goods equal to net-of-tax earnings $w_{i} h_{m i}\left(1-\tau_{i}\right)$ (where $w_{i}$ is the wage and $\tau_{i}$ is the tax rate), $c_{n i}$ is consumption of non-market goods, $h_{m i}$ is market work, $h_{n i}$ is non-market work, $v_{i}$ is the utility of leisure, and all agents have the same production technology $c_{n i}^{e}=B h_{n i}$, then the first order condition for agent $\mathrm{i}$ implies

$$
\ln \left(h_{m i} / h_{n i}\right)=\frac{1}{e-1} \ln (B)-\frac{e}{e-1} \ln \left(w_{i}\right)-\frac{e}{e-1} \ln \left(1-\tau_{i}\right)+\frac{1}{e-1} \ln \left(\frac{1-a_{i}}{a_{i}}\right)
$$

\footnotetext{
${ }^{30}$ Burda and Hamermesh (2009) do find, however, that in areas in which unemployment has suddenly risen, individuals offset the loss of market work with an increase in home production. Richard Freeman and Ronald Schettkat (2005) find that individuals work more in the market and less at home in the U.S. than in Europe, but Alberto Alesina, Edward Glaeser, and Bruce Sacerdote (2006) and Burda, Hamermesh, and Weil (2008) find little evidence for this.
} 
Assuming that the final term is a constant that is taken out by individual fixed effects, and that the wage $w_{i}$ changes equally for individuals in the treatment and control groups in the empirical analysis (as our data bear out) so that the wage term can be treated as a constant, we can estimate $e /(e-1)$ by dividing the elasticity of market work with respect to the net-of-tax share by the elasticity of housework with respect to the net-of-tax share. Our baseline estimates of the relevant elasticities imply that $e$ is $.59,{ }^{31}$ which is remarkably close to their estimate of $.60 .^{32}$ This implies that the elasticity of substitution $1 /(1-e)$ of market and home consumption is 2.43 . Our baseline estimates also allow us to calculate that the changes in tax policy documented here should have caused a decrease of 3.50 hours per week of housework, $43 \%$ of the actual decrease. In light of the fact that microeconomic studies tend to estimate smaller labor supply elasticities than macroeconomic studies (Edward Prescott 2004; Rogerson and Johanna Wallenius 2009), it is noteworthy that we examine a panel of 30 years and estimate an elasticity of labor supply that is still well below what is typically estimated in studies in the macroeconomics literature.

Future work could fruitfully examine a number of further questions. Further work on a dynamic model of labor supply, housework, leisure, and consumption decisions would be relevant. Valuing the output of housework or home production would be relevant to welfare analysis. The estimates could be used as inputs into a calculation of equivalence weights in lifecycle analysis (e.g. John Laitner and Daniel Silverman 2005). Finally, investigating how public policy affects married couples' decisions about housework, labor supply, leisure, and consumption would be a natural extension of the issues examined in this paper.

\footnotetext{
${ }^{31}$ When we implement this specification more directly by regressing the log of the ratio of market work to housework on the log of the net-of-tax share and the controls in our baseline specification (adding one to both market work and housework before logging so that we include zeroes in the regression), we estimate a coefficient on the $\log$ net-of-tax share of 2.39 with a standard error of .39, implying that the elasticity of substitution is 3.39 . Adding 5 to both market work and housework before logging yields an elasticity of substitution of 2.56.

${ }^{32}$ Peter Rupert, Rogerson, and Wright (1995) estimate an elasticity of substitution between home and market goods for single women of 1.8. Aguiar and Hurst (2007b) estimate an elasticity of substitution between time and goods in home production for single women of 1.95 .
} 


\section{References}

Aguiar, Mark, and Erik Hurst. 2007a. "Measuring Trends in Leisure: The Allocation of Time over Five Decades.” Quarterly Journal of Economics, 122: 969-1006.

Aguiar, Mark, and Erik Hurst. 2007b. "Life-Cycle Prices and Production." American Economic Review, 97: 1533-1559.

Alesina, Alberto, Edward Glaeser, and Bruce Sacerdote. 2006. "Work and Leisure in the U.S. and Europe: Why So Different?" in NBER Macroeconomics Annual 2005.

Alm, James, and Leslie A. Whittington. 1995. "Does the Income Tax Affect Marital Decisions?” National Tax Journal, 48: 565-572.

Becker, Gary. 1965. "A Theory of the Allocation of Time." Economic Journal, 125: 493-517.

Becker, Gary, and Gilbert Ghez. 1975. The Allocation of Time and Goods Over the Life Cycle. Chicago, IL: NBER.

Benhabib, Jess, Richard Rogerson, and Randall Wright. 1991. "Homework in Macroeconomics: Household Production and Aggregate Fluctuations." Journal of Political Economy, 99: 1166-1187.

Biddle, Jeff E., and Daniel Hamermesh. 1990. "Sleep and the Allocation of Time." Journal of Political Economy, 98: 922-943.

Blank, Rebecca M. 2002. "Evaluating Welfare Reform in the United States." Journal of Economic Literature, 50: 1105-1166.

Blau, Francine D., and Lawrence M. Kahn. 2007. "Changes in the Labor Supply Behavior of Married Women: 1980-2000." Journal of Labor Economics, 25: 393-438.

Blundell, Richard, and Thomas MaCurdy. 1999. "Labor Supply: A Review of Alternative Approaches." Handbook of Labor Economics, 3: 1559-1695.

Burda, Michael, and Daniel Hamermesh. 2009. "Unemployment, Market Work, and Household Production.” NBER Working Paper No.14676.

Burda, Michael, Daniel Hamermesh and Philippe Weil. 2008. "The Distribution of Total Work in the EU and US." In Working Hours and Job Sharing in the EU and USA: Are Americans Crazy? Are Europeans Lazy? eds. Tito Boeri, Michael Burda and Francis Kramarz. New York: Oxford University Press.

Charles, Kerwin, Erik Hurst, and Nikolai Roussanov. 2009. "Conspicuous Consumption and Race." Quarterly Journal of Economics, 124: 425-467.

DeLeire, Thomas, and Helen Levy. 2005. "The Material Well-Being of Single Mother Households in the 1980s and 1990s: What Can We Learn from Food Spending?" National Poverty Center Working Paper No. 01-05.

Eissa, Nada, and Hilary Hoynes. 2004. "Taxes and the Labor Market Participation of Married Couples: the Earned Income Tax Credit.” Journal of Public Economics, 88: 1931-1958.

Eissa, Nada, and Hilary Hoynes. 2006. "Behavioral Responses to Taxes: Lessons from the EITC and Labor Supply." Tax Policy and the Economy, 20: 73-110.

Eissa, Nada, Henrik Kleven, and Claus Kreiner. 2008. "Evaluation of Four Tax Reforms in the United States: Labor Supply and Welfare Effects for Single Mothers." Journal of Public Economics, 92: 795-816.

Eissa, Nada, and Jeffrey B. Liebman. 1996. "Labor Supply Response to the Earned Income Tax Credit." Quarterly Journal of Economics, 111: 605-637.

Feenberg, Daniel, and Elisabeth Coutts. 1993. "An Introduction to the TAXSIM Model." Journal of Policy Analysis and Management, 12: 189-194.

Gelber, Alexander. 2009. "Taxation and Family Labor Supply.” NBER Working Paper. 
Greenwood, Jeremy, Ananth Seshadri, and Mehmet Yorukoglu. 2005. "Engines of Liberation," Review of Economic Studies, 72: 109-133.

Gronau, Reuben. 1977. "Leisure, Home Production, and Work - the Theory of the Allocation of Time Revisited." Journal of Political Economy, 85: 1099-1123.

Gruber, Jonathan and Emmanuel Saez. 2002. "The Elasticity of Taxable Income: Evidence and Implications." Journal of Public Economics, 84: 1-32.

Hamermesh, Daniel. 2008. "Direct Estimates of Household Production." Economics Letters, 98: 31-34.

Hamermesh, Daniel, and G.A. Pfann. 2005. The Economics of Time Use. Amsterdam, Netherlands: Elsevier.

Hotz, V. Joseph, and John Karl Scholz. 2003. "The Earned Income Tax Credit." In MeansTested Transfer Programs in the United States, ed. Robert Moffitt. Chicago: University of Chicago Press and NBER.

Juster, Thomas, and Frank Stafford, eds. 1985. Time, Goods and Well-Being. Ann Arbor, MI: University of Michigan Press.

Knowles, John. 2005. “Why are Married Men Working So Much?” University of Pennsylvania Working Paper.

Laitner, John, and Daniel Silverman. 2005. "Estimating Life-cycle Parameters from Consumption Behavior at Retirement." NBER Working Paper 11163.

Meyer, Bruce. 2009. "The Effects of the EITC and Recent Reforms." In Tax Policy and the Economy, Jeffrey Brown, ed. Boston, MA: M.I.T. Press.

Meyer, Bruce, and Dan Rosenbaum. 2001. "Welfare, the Earned Income Tax Credit, and the Labor Supply of Single Mothers.” Quarterly Journal of Economics, 116: 1063-1114.

Meyer, Bruce, and James X. Sullivan. 2008. "Changes in the Consumption, Income, and WellBeing of Single Mother Headed Families.” American Economic Review, 98: 221-241.

Meyer, Bruce, and James X. Sullivan. 2004. "The Effects of Welfare and Tax Reform: The Material Well-Being of Single Mothers in the 1980s and 1990s." Journal of Public Economics, 88: 1387-1420.

Moffitt, Robert. 2003. "The Temporary Assistance for Needy Families Program.” In MeansTested Transfer Programs in the United States, ed. Robert Moffitt. Chicago: University of Chicago Press and NBER.

Moffitt, Robert. 2006. "Welfare Work Requirements with Paternalistic Government Preferences.” Economic Journal, 116: 441-458.

Moffitt, Robert, and Mark O. Wilhelm. 2000. "Taxation and the Labor Supply Decision of the Affluent." In Does Atlas Shrug? Economic Consequences of Taxing the Rich, ed. Joel Slemrod. Cambridge, MA: Russell Sage Foundation and Harvard University Press.

Prescott, Edward. 2004. "Why Do Americans Work So Much More than Europeans?" Federal Reserve Bank of Minneapolis Quarterly Review, 28: 2-13.

Ramey, Valerie. 2008. "How Much has Leisure Really Increased Since 1965?” UC San Diego Working Paper.

Rogerson, Richard, and Johanna Wallenius. 2009. "Micro and Macro Elasticities in a Life Cycle Model with Taxes." Journal of Economic Theory, forthcoming.

Robinson, John, and Geoffrey Godbey. 1999. Time for Life. University Park, PA: Pennsylvania State University Press.

Rupert, Peter, Richard Rogerson, and Randall Wright. 1995. "Estimating Substitution Elasticities in Household Production Models.” Economic Theory, 6(1): 179-93. 


\section{Data Appendix}

Panel Study of Income Dynamics (PSID): The PSID is a large representative longitudinal survey that contains detailed information on a wide array of topics including demographics, labor market participation, housework, and income. Individuals in family units were surveyed ever year from 19681997 and every two years thereafter. Our analysis covers survey years 1976-2005 (excluding survey year 1982) because hours of housework are consistently measured only during these years. The sample is restricted to members of and movers into the core sample but excludes the poverty sample. We focus on unmarried and non-cohabitating female heads of household age 25-55 who are present in the PSID for at least two years. ${ }^{33}$ We further exclude observations that have allocated values for hours of work and housework. Weights are used throughout to ensure the sample remains representative.

The PSID asks for usual weekly hours of housework as follows: "About how much time do you spend on housework in an average week? I mean time spent cooking, cleaning, and doing other work around the house." We measure usual weekly hours worked in the previous calendar year. We use responses to several questions to construct this variable. The PSID asks about work at a main job in the previous calendar year. The following is the typical main job hours question: "We're interested in how you spent your time from January through December < previous calendar year $>$... On the average, how many hours a week did you work on your main job(s)." The PSID then asks respondents about extra jobs: "Did you have an extra job or other way of making money in addition to your main job in <previous calendar year $>$ ?.... On the average, how many hours a week did you work on this job?" Responses to the main and extra jobs questions are then added together to form our measure of total usual weekly hours worked per week. $^{34}$

The mean of our measure of usual weekly hours worked is 37.47 , whereas for the same population over the same set of years in the Current Population Survey (CPS), the mean of usual weekly hours worked is 32.32. This discrepancy is largely explained by labor force participation rates: over the full sample period, in the CPS, $81.31 \%$ of the population of female heads of household aged 25-55 reported doing any work last year, whereas $89.25 \%$ of the sample reported doing any work last year in the PSID. In light of these discrepancies, it is worth noting that despite these differences in the level of hours worked, the trend over time in hours worked in the full sample is extremely similar in the PSID and CPS, as is the relative trend among women with and without children. Indeed, when we run the same set of regressions on the same sample population in the CPS with hours worked as the dependent variable and the net-of-tax share as the independent variable (as well as the other regressors that appear in the PSID except individual fixed effects), we obtain similar results to those we obtain in the PSID when we remove individual fixed effects from the estimation. The coefficient on the net-of-tax share when a dummy for labor force participation is the dependent variable is .33 in the CPS (standard error .0097; $\mathrm{N}=365,703$ ); the coefficient in the PSID when we remove individual fixed effects (but control for education dummies that appear in the imputation but are absorbed by the fixed effects in the main specification) is 34 (standard error .08; $\mathrm{N}=9,242$ ). The coefficient on the net-of-tax share when usual hours worked is the dependent variable is 11.15 in the CPS (standard error .43; $\mathrm{N}=365,703$ ); the coefficient in the PSID

\footnotetext{
${ }^{33}$ Our sample excludes what the PSID calls "permanent" cohabitators defined as having lived together for at least a year or present for two or more waves of data collection. There remain a small number of "temporary" cohabitators in our sample.

${ }^{34}$ Before asking about work at main and extra jobs, the PSID first asks respondents to report current employment status. Regardless of the answer to the current employment status question, the PSID then asks the questions above about previous calendar year work experience, but respondents' answers are coded as one variable if the respondent is currently employed, and a second variable if the respondent is not currently employed. We naturally combine these responses (for those currently employed and not) to form our measure of previous calendar year work hours.
} 
when we remove individual fixed effects (but control for education dummies) is 12.89 (standard error $4.35 ; \mathrm{N}=9,242)$.

The PSID also contains a constructed measure of total annual hours in the previous calendar year. Total annual hours is defined as the sum over all jobs of the product of total weeks worked and usual weekly hours worked plus total annual overtime hours. We define a binary variable for labor force participation as equal to one if the respondent has positive usual hours worked and zero otherwise. We define "residual time" in the PSID as total hours in a week (168) less usual hours of housework less usual hours of market work.

Time Use Data: We draw on four cross-sections of time use data assembled and described in great detail in Aguiar and Hurst (2007a). ${ }^{35}$ These data ask respondents to account for time spent during the previous day. We use data from the 1975 Time Use in Economic and Social Accounts, the 1985 Americans' Use of Time, the 1993 National Human Activity Pattern Survey, and 2003 American Time Use Survey. We choose these datasets because they are nationally representative and overlap with the period of analysis in the PSID. We also add the 2004 year of the American Time Use Survey to increase sample size and correspond exactly with the final year of analysis in the PSID. We use Aguiar and Hurst's coding of activities and refer the reader to their variable glossary. Given the lack of consistent labor income data in the time use surveys, we instead impute labor income for each respondent using demographic information and the coefficients obtained from the PSID labor income imputation described in the text. We then feed imputed labor income into TAXSIM to calculate the simulated average net-of-tax share. We use weights throughout and follow Aguiar and Hurst (2007a) in weighting each survey equally.

We select our sample to be as consistent as possible across survey years as well as with the PSID sample. In all years we require non-missing data on education and number of children, as well as complete time diaries that account for activities in all 168 hours in a week. We select the sample as follows: 1975: unmarried female heads of household age $25-55$; 1985: unmarried females who answered the telephone survey age 25-55; 1993: female adults living in one adult household age 25-55; 2003/2004: unmarried female heads of household age 25-55.

Consumer Expenditure Survey: Total food, food away from home, food at home, and food at work are coded consistently with the National Income and Product Accounts expenditure categories. Total food is calculated by summing food away from home, food at home, and food at work. Data on expenditures on domestic services and major appliances are taken from the quarterly CEX interview files. Domestic services include babysitting, day care, and hired help for cleaning. The underlying CEX UCC codes are 340310, 340410, 340420, 340520, 340530, 340903, 340906, 340914, 340210, 340211, 340212, and 670310. Expenditure on major appliances is calculated as expenditures on washers, dryers, stove ovens, microwave ovens, portable dishwashers, electric cleaning equipment, and refrigerators (UCC codes 300210, 300220, 300310, 300320, 300330, 320511, and 300110).

Since state of residence is missing for a substantial fraction of the sample, we use only Federal tax variation for identifying the estimates; we obtain similar results when we use the state data that are available. For comparability with the NBER data, we collapse the raw quarterly data to the yearly level by summing expenditures across a year. To address attrition, we follow Charles, Hurst, and Roussanov (2009) in imputing expenditures in quarters in which an individual is missing by assuming that a woman would have spent as much in the quarters in which data is missing as the average amount she spent in the quarters in which she is in the data. We use survey weights throughout. All dollar amounts are expressed in real 2005 dollars.

\footnotetext{
${ }^{35}$ The data are available for download at http://troi.cc.rochester.edu/ maguiar/timeuse_data/datapage.html
} 
Figure 1. Changes in tax rates over time: mean imputed average net-of-tax share by year for single women with and without children

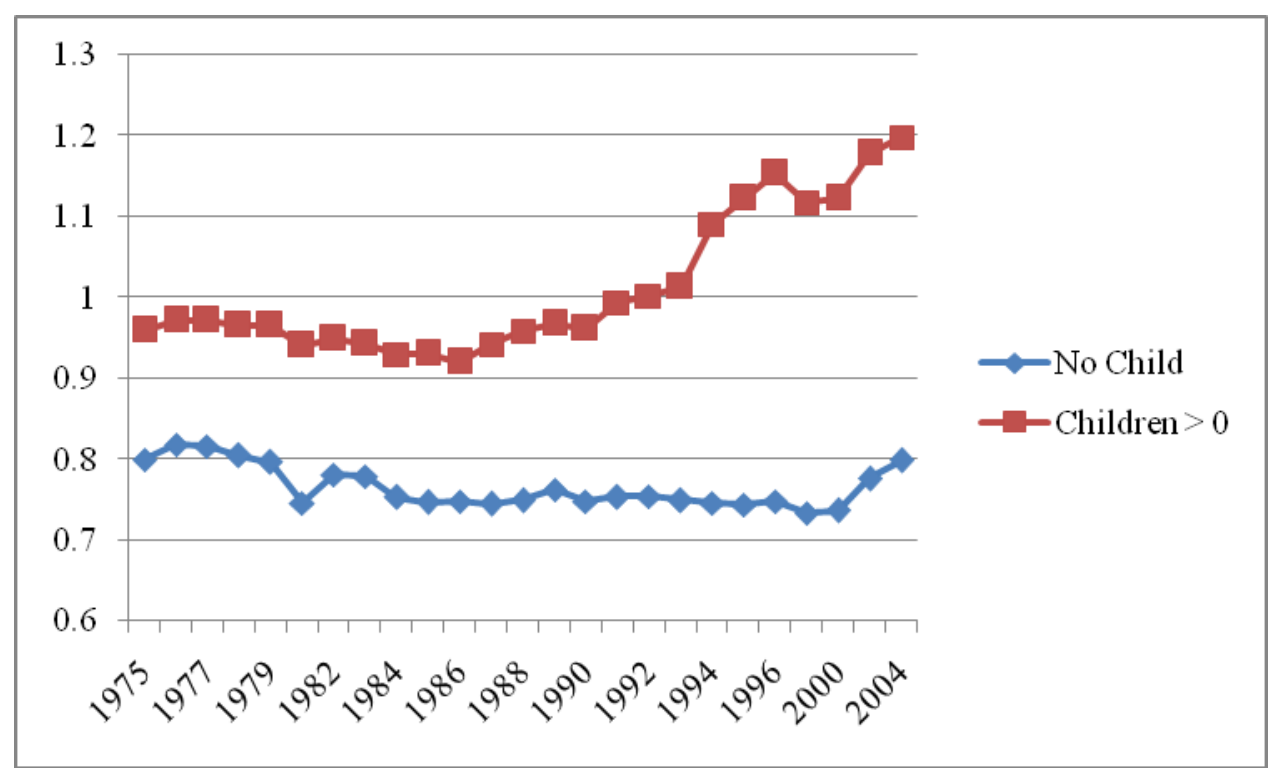

Notes: The figure shows that starting in the mid-1980s, there was an increasing incentive to participate in the labor force for low-income single women with children relative to those without children: the average net-of-tax share (defined as the share of earnings a woman keeps if she participates in the labor force) rose substantially for single women with children relative to those without children. Average tax rates are calculated using Taxsim by calculating a woman's tax liability if she works and if she does not work, and then calculating the fraction of her earnings that would be taken away in taxes if she works. A woman's tax liability if she works is calculated by applying Taxsim to the woman's imputed earnings. Earnings are imputed by regressing earnings on age, number of children, education, and year fixed effects in the full sample and deriving the fitted values, as described in Section 3. The average net-of-tax share for women with children is greater than one primarily because the EITC transfers a substantial amount of money to a low-income woman if she works, often implying that the effective tax rate is negative. The data are taken from the Panel Study of Income Dynamics. 
Figure 2. Mean usual hours of market work and housework of single women with and without children, 1975-2004

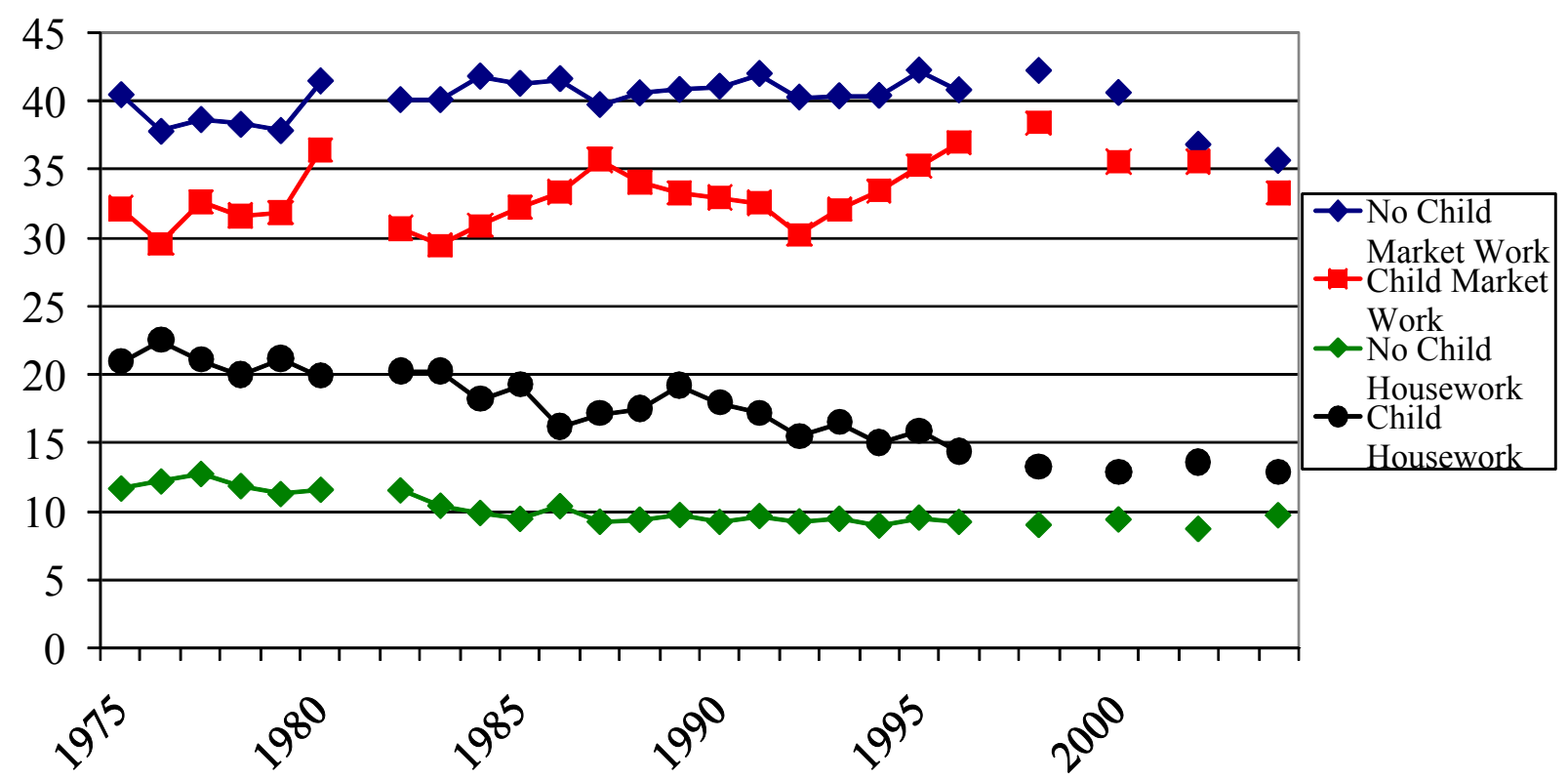

Notes: The data are taken from the Panel Study of Income Dynamics. The figure shows mean usual hours worked and usual hours of housework for single female heads of household aged 2555 , excluding cohabitators, with and without children. The figure shows that mean usual hours of market work increased substantially for single women with children relative to those without children from the mid-1980s to the mid-to-late 1990s, a period coincident with the relative tax policy changes shown in Figure 1. During this period, mean hours of housework fell substantially for women with children relative to those without. This suggests that much of the increase in hours of market work during this period corresponded to a decrease in hours of housework. During the period without the policy changes that differentially affected women with and without children, there is little discernable trend in housework and market work for single women with children relative to those without. 
Figure 3. Additional identifying variation: mean change in usual weekly hours of market work and housework in high and low income groups (y-axis), plotted against mean change in net-oftax share in high and low income groups (x-axis), among women with children

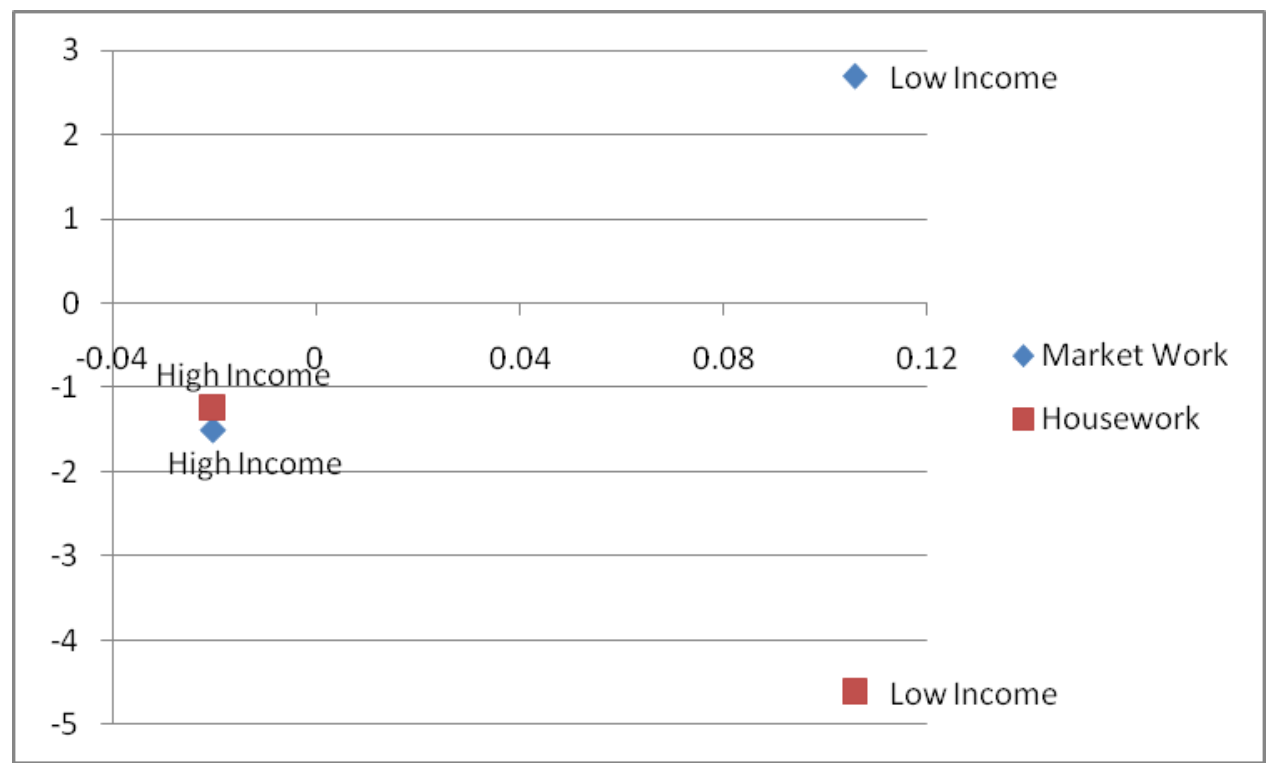

Notes: Figure 3 shows that among women with children, the mean tax cut was larger for lowerincome individuals than for high-income individuals, and the mean increase in market work and decrease in housework was also larger for low-income individuals than for high-income individuals. This demonstrates that in addition to the identifying variation shown in Figures 1 and 2 coming from a comparison across women with and without children over time, there is additional identifying variation stemming from a comparison of changes in market/home work and taxes in low and high income groups over time. "High income" refers to individuals with imputed income above the median, and "low income" refers to all others. The "change" in market work, housework, and the net-of-tax share is computed by calculating the change in the mean of the variables from the 1975-1986 period to the 1987-2004 period. 
Table 1. Means and Standard Deviations of Main Variables

Panel A: PSID

\begin{tabular}{|c|c|}
\hline & Mean (Standard Deviation) \\
\hline Work $>0$ Hours During the Year & $.89(.31)$ \\
\hline Weekly Hours Worked & $37.47(17.54)$ \\
\hline Weekly Housework & $12.66(10.55)$ \\
\hline Weekly Residual Time & $117.86(17.75)$ \\
\hline Average Net-of-Tax Share & $.86(.16)$ \\
\hline Age & $38.72(8.82)$ \\
\hline Number of Children & $.71(1.04)$ \\
\hline $\mathrm{N}$ & 9,242 \\
\hline \multicolumn{2}{|l|}{ Panel B: Time Diary Data } \\
\hline & "Mean (Standard Deviation) \\
\hline Work $>0$ Hours During the Week & $.75(.43)$ \\
\hline Weekly Hours Worked & $27.34(29.53)$ \\
\hline Weekly Housework & $6.13(10.37)$ \\
\hline Weekly Home Production & $14.17(15.55)$ \\
\hline Weekly Non-Market Work & $19.91(18.69)$ \\
\hline Weekly Leisure 1 & $33.83(23.56)$ \\
\hline Weekly Leisure 2 & $107.39(27.47)$ \\
\hline Weekly Leisure 3 & $112.31(27.61)$ \\
\hline Weekly Food Preparation and Eating & $12.29(9.85)$ \\
\hline Weekly Sleep & $59.06(16.24)$ \\
\hline Weekly Child Care & $4.91(9.92)$ \\
\hline Average Net-of-Tax Share & $.94(.17)$ \\
\hline Age & $39.14(9.04)$ \\
\hline Number of Children & $.91(1.24)$ \\
\hline $\mathrm{N}$ & 4,444 \\
\hline \multicolumn{2}{|l|}{ Panel C: Consumer Expenditure Survey } \\
\hline & "Mean (Standard Deviation) \\
\hline Food & $2846.71(2135.78)$ \\
\hline Food Away from Home & $697.95(995.62)$ \\
\hline Food at Home & $2122.99(1629.11)$ \\
\hline Food at Work & $25.77(178.47)$ \\
\hline Domestic Services & $236.77(792.97)$ \\
\hline Major Appliances & $88.78(329.59)$ \\
\hline Average Net-of-Tax Share & $.91(.17)$ \\
\hline Age & $38.15(8.78)$ \\
\hline Number of Children & $.88(1.18)$ \\
\hline $\mathrm{N}$ & 25,395 \\
\hline
\end{tabular}

Notes: The table shows the means and standard deviations of the central variables in the analysis. In Panel A, the sample is taken from the PSID data from 1975-2004. In Panel B, the data are taken from repeated cross sections on time use assembled by Aguiar and Hurst (2007a) and the 2004 American Time Use Survey, spanning 1975-2004. Panel C shows data from the Consumer Expenditure Survey from 1980-2003. Expenditure amounts are expressed in real 2005 dollars. The sample consists of unmarried female heads of household aged 25-55. 
Table 2. Regressions of time allocations on imputed average net-of-tax share, non-labor income, individual fixed effects, and control variables

Panel A: Dependent Variable is Dummy for Labor Force Participation

\begin{tabular}{|c|c|c|c|c|c|c|c|c|c|}
\hline & $\begin{array}{c}(1) \\
\text { Basic } \\
\text { Controls }\end{array}$ & $\begin{array}{c}(2) \\
\text { Control for } \\
\text { Self- } \\
\text { Selection }\end{array}$ & $\begin{array}{c}(3) \\
\text { Control for } \\
\text { Welfare }\end{array}$ & $\begin{array}{c}(4) \\
\text { Sample is } \\
\text { pre-1993 }\end{array}$ & $\begin{array}{c}(5) \\
\text { IV for } \\
\text { Non-Labor } \\
\text { Income }\end{array}$ & $\begin{array}{l}(6) \\
\text { IV for } \\
\text { ANTR }\end{array}$ & $\begin{array}{c}(7) \\
\text { IV for Net- } \\
\text { of-Tax } \\
\text { Wage }\end{array}$ & $\begin{array}{c}(8) \\
\text { Extra } \\
\text { Controls }\end{array}$ & $\begin{array}{c}(9) \\
\text { Extra } \\
\text { Fixed } \\
\text { Effects }\end{array}$ \\
\hline ANTR & $\begin{array}{c}.45 \\
(.08)^{* * *}\end{array}$ & $\begin{array}{c}.43 \\
(.13)^{* * *}\end{array}$ & $\begin{array}{c}.44 \\
(.08)^{* * *}\end{array}$ & $\begin{array}{c}.71 \\
(.18)^{* * *}\end{array}$ & $\begin{array}{c}.44 \\
(.09)^{* * *}\end{array}$ & $\begin{array}{c}1.15 \\
(.22)^{* * *}\end{array}$ & & $\begin{array}{c}.35 \\
(.09)^{* * *}\end{array}$ & $\begin{array}{c}.28 \\
(.11)^{* * *}\end{array}$ \\
\hline $\begin{array}{l}\text { Non-Labor } \\
\text { Inc. } \\
\text { Welfare } \\
\text { ATR }\end{array}$ & $\begin{array}{l}.00008 \\
(.001)\end{array}$ & $\begin{array}{l}.00006 \\
(.001)\end{array}$ & $\begin{array}{c}.0001 \\
(.01) \\
.05 \\
(.04)\end{array}$ & $\begin{array}{c}.0002 \\
(.0002) \\
.03 \\
(.05)\end{array}$ & $\begin{array}{l}-.01 \\
(.02) \\
.04 \\
(.05)\end{array}$ & $\begin{array}{l}.002 \\
(.01)\end{array}$ & $\begin{array}{c}.000001 \\
(.001)\end{array}$ & $\begin{array}{c}.00006 \\
(.01) \\
.033 \\
(.041)\end{array}$ & $\begin{array}{l}.0003 \\
(.001)\end{array}$ \\
\hline Net Wage & & & & & & & $\begin{array}{c}.03 \\
(.005)^{* * *}\end{array}$ & & \\
\hline R-Squared & 0.04 & .04 & .04 & .04 & & & & .06 & .28 \\
\hline $\mathrm{N}$ & 9,242 & 9,242 & 9,242 & 5,736 & 9,242 & 9,242 & 9,242 & 9,242 & 9,242 \\
\hline Elasticity & .43 & .42 & .43 & .68 & .43 & 1.11 & .40 & .34 & .27 \\
\hline
\end{tabular}

Notes: "ANTR" refers to the average net-of-tax rate, calculated using income imputed with demographics, as described in the text. The average net-of-tax rate is the percentage of income that a woman would keep if she participated in the labor force. Standard errors are clustered by

individual. Each regression has 1,243 clusters. All regressions control for dummies for all possible values of age and number of children, as well as individual and year fixed effects; this is also the set of "basic controls" used in Column 1. Column 2 uses a Heckman selection correction in imputing income, as described in the text. Column 3 controls for the incentives created by AFDC, TANF, and food stamps, summarized by the variable "Welfare ATR," equal to the difference between welfare benefits if a woman works and does not, as a fraction of earnings if she works.

Column 4 limits the sample to the period before 1993. Column 5 instruments for non-labor income with the value of the welfare benefits a woman would receive if she did not work. Column 6 instruments for one measure of the average net-of-tax share using another measure, as described in the text. Column 7 instruments for the imputed net-of-tax wage using the average net-of-tax share. Column 8 adds controls for the state minimum wage, state GDP, the presence of a welfare waiver, average labor income interacted with year, and education-by-year fixed effects. Column 9 controls for number-of-child-by-year, number-of-child-by-state, and state-by-year fixed effects. The actual coefficients and standard errors on non-labor income have been multiplied by 1,000 . "Elasticity" refers to the implied elasticity of the dependent variable with respect to the ANTR, calculated at the means. $* * *$ denotes significance at $1 \% ; * *$ at $5 \% ; *$ at $10 \%$. 
Table 2, Panel B: Dependent Variable is Usual Weekly Hours of Market Work

\begin{tabular}{|c|c|c|c|c|c|c|c|c|c|}
\hline & $\begin{array}{c}(1) \\
\text { Basic } \\
\text { Controls }\end{array}$ & $\begin{array}{c}(2) \\
\text { Control for } \\
\text { Self- } \\
\text { Selection }\end{array}$ & $\begin{array}{c}(3) \\
\text { Control for } \\
\text { Welfare }\end{array}$ & $\begin{array}{c}(4) \\
\text { Sample is } \\
\text { pre-1993 }\end{array}$ & $\begin{array}{c}(5) \\
\text { IV for } \\
\text { Non-Labor } \\
\text { Income } \\
\end{array}$ & $\begin{array}{c}(6) \\
\text { IV for } \\
\text { ANTR }\end{array}$ & $\begin{array}{c}(7) \\
\text { IV for Net- } \\
\text { of-Tax } \\
\text { Wage }\end{array}$ & $\begin{array}{c}(8) \\
\text { Extra } \\
\text { Controls }\end{array}$ & $\begin{array}{c}(9) \\
\text { Extra } \\
\text { Fixed } \\
\text { Effects }\end{array}$ \\
\hline ANTR & $\begin{array}{c}18.87 \\
(4.86)^{* * * *}\end{array}$ & $\begin{array}{c}25.48 \\
(7.76)^{* * *}\end{array}$ & $\begin{array}{c}18.67 \\
(4.83)^{* * *}\end{array}$ & $\begin{array}{c}29.78 \\
(10.11)^{* * *}\end{array}$ & $\begin{array}{c}17.81 \\
(5.60)^{* * *}\end{array}$ & $\begin{array}{c}47.78 \\
(12.28)^{* * *}\end{array}$ & & $\begin{array}{c}16.86 \\
(5.43)^{* * *}\end{array}$ & $\begin{array}{c}5.18 \\
(6.05)\end{array}$ \\
\hline $\begin{array}{l}\text { Non-Labor } \\
\text { Inc. } \\
\text { Welfare } \\
\text { ATR }\end{array}$ & $\begin{array}{l}-.02 \\
(.06)\end{array}$ & $\begin{array}{l}-.02 \\
(.06)\end{array}$ & $\begin{array}{c}-.023 \\
(.060) \\
1.06 \\
(1.83)\end{array}$ & $\begin{array}{c}-.015 \\
(.073) \\
.87 \\
(2.49)\end{array}$ & $\begin{array}{c}-1.52 \\
(1.28) \\
-.98 \\
(2.46)\end{array}$ & $\begin{array}{l}-.020 \\
(.060)\end{array}$ & $\begin{array}{l}-.027 \\
(.061)\end{array}$ & $\begin{array}{c}-.033 \\
(.060) \\
.53 \\
(1.89)\end{array}$ & $\begin{array}{l}-.030 \\
(.057)\end{array}$ \\
\hline Net Wage & & & & & & & $\begin{array}{c}1.24 \\
(.32)^{* * *}\end{array}$ & & \\
\hline R-Squared & .04 & .04 & .04 & .03 & & & & .06 & .26 \\
\hline $\mathrm{N}$ & 9,242 & 9,242 & 9,242 & 5,736 & 9,242 & 9,242 & 9,242 & 9,242 & 9,242 \\
\hline Elasticity & .43 & .58 & .43 & .68 & .41 & 1.10 & .40 & .39 & .12 \\
\hline
\end{tabular}

Notes: "ANTR" refers to the average net-of-tax rate, calculated using income imputed with demographics, as described in the text. The average net-of-tax rate is the percentage of income that a woman would keep if she participated in the labor force. Standard errors are clustered by individual. Each regression has 1,243 clusters. All regressions control for dummies for all possible values of age and number of children, as well as individual and year fixed effects; this is also the set of "basic controls" used in Column 1. Column 2 uses a Heckman selection correction in imputing income, as described in the text. Column 3 controls for the incentives created by AFDC, TANF, and food stamps. These incentives are summarized by the variable "Welfare ATR," which is equal to the difference between welfare benefits if a woman works and does not, as a

fraction of the woman's earnings if she works. Column 4 limits the sample to the period before 1993. Column 5 instruments for non-labor income with the value of the welfare benefits a woman would receive if she did not work. Column 6 instruments for one measure of the average net-of-tax share using another measure, as described in the text. Column 7 instruments for the net-of-tax wage using the average net-of-tax share. Column 8 adds controls for the state minimum wage, state GDP, the presence of a welfare waiver, average labor income interacted with year, and educationby-year fixed effects. Column 9 adds number-of-child-by-year, number-of-child-by-state, and state-by-year fixed effects. The actual coefficients and standard errors on non-labor income have been multiplied by 1,000. "Elasticity" refers to the implied elasticity of the dependent variable with respect to the ANTR, calculated at the means. *** denotes significance at $1 \% ; * *$ at $5 \% ; *$ at $10 \%$. 
Table 2, Panel C: Dependent Variable is Usual Weekly Hours of Housework

\begin{tabular}{|c|c|c|c|c|c|c|c|c|c|}
\hline & $\begin{array}{c}(1) \\
\text { Basic } \\
\text { Controls }\end{array}$ & $\begin{array}{c}(2) \\
\text { Control } \\
\text { for Self- } \\
\text { Selection }\end{array}$ & $\begin{array}{c}(3) \\
\text { Control } \\
\text { for } \\
\text { Welfare }\end{array}$ & $\begin{array}{c}(4) \\
\text { Sample is } \\
\text { pre-1993 }\end{array}$ & $\begin{array}{c}\text { (5) } \\
\text { IV for } \\
\text { Non- } \\
\text { Labor } \\
\text { Income }\end{array}$ & $\begin{array}{l}\text { (6) } \\
\text { IV for } \\
\text { ANTR }\end{array}$ & $\begin{array}{c}(7) \\
\text { IV for } \\
\text { Net-of- } \\
\text { Tax } \\
\text { Wage }\end{array}$ & $\begin{array}{c}(8) \\
\text { Extra } \\
\text { Controls }\end{array}$ & $\begin{array}{c}(9) \\
\text { Extra } \\
\text { Fixed } \\
\text { Effects }\end{array}$ \\
\hline ANTR & $\begin{array}{c}-14.65 \\
(2.36)^{* * *}\end{array}$ & $\begin{array}{c}-16.17 \\
(4.04)^{* * *}\end{array}$ & $\begin{array}{c}-14.87 \\
(2.36)^{* * *}\end{array}$ & $\begin{array}{c}-14.14 \\
(6.35)^{* *}\end{array}$ & $\begin{array}{c}-15.33 \\
(2.96)^{* * *}\end{array}$ & $\begin{array}{c}-37.11 \\
(6.49)^{* * *}\end{array}$ & & $\begin{array}{c}-12.25 \\
(2.67)^{* * *}\end{array}$ & $\begin{array}{c}-7.95 \\
(3.42)^{* *}\end{array}$ \\
\hline Non-Labor Inc. & $\begin{array}{l}.017 \\
(.021)\end{array}$ & $\begin{array}{l}.018 \\
(.021)\end{array}$ & $\begin{array}{l}.018 \\
(.021)\end{array}$ & $\begin{array}{l}.031 \\
(.028)\end{array}$ & $\begin{array}{l}-.73 \\
(.81)\end{array}$ & $\begin{array}{l}.015 \\
(.022)\end{array}$ & $\begin{array}{l}.020 \\
(.021)\end{array}$ & $\begin{array}{l}-.013 \\
(.022)\end{array}$ & $\begin{array}{l}-.006 \\
(.020)\end{array}$ \\
\hline Welfare ATR & & & $\begin{array}{c}1.16 \\
(1.26)\end{array}$ & $\begin{array}{c}.08 \\
(1.76)\end{array}$ & $\begin{array}{c}.16 \\
(1.74)\end{array}$ & & & $\begin{array}{c}1.51 \\
(1.30)\end{array}$ & \\
\hline Net Wage & & & & & & & $\begin{array}{c}-.96 \\
(.15)^{* * *}\end{array}$ & & \\
\hline R-Squared & .09 & .09 & .09 & .08 & & & & .11 & .29 \\
\hline $\mathrm{N}$ & 9,242 & 9,242 & 9,242 & 5,736 & 9,242 & 9,242 & 9,242 & 9,242 & 9,242 \\
\hline Elasticity & -1.00 & -1.10 & -1.01 & .96 & -1.04 & -2.52 & -.91 & -.84 & -.54 \\
\hline
\end{tabular}

Notes: "ANTR" refers to the average net-of-tax rate, calculated using income imputed with demographics, as described in the text. The average net-of-tax rate is the percentage of income that a woman would keep if she participated in the labor force. Standard errors are clustered by individual. Each regression has 1,243 clusters. All regressions control for dummies for all possible values of age and number of children, as well as individual and year fixed effects; this is also the set of "basic controls" used in Column 1. Column 2 uses a Heckman selection correction in imputing income, as described in the text. Column 3 controls for the incentives created by AFDC, TANF, and food stamps. These incentives are summarized by the variable "Welfare ATR," which is equal to the difference between welfare benefits if a woman works and does not, as a fraction of the woman's earnings if she works. Column 4 limits the sample to the period before 1993. Column 5 instruments for non-labor income with the value of the welfare benefits a woman would receive if she did not work. Column 6 instruments for one measure of the average net-of-tax share using another measure, as described in the text. Column 7 instruments for the net-of-tax wage using the average net-of-tax share. Column 8 adds controls for the state minimum wage, state GDP, the presence of a welfare waiver, average labor income interacted with year, and educationby-year fixed effects. Column 9 adds number-of-child-by-year, number-of-child-by-state, and state-by-year fixed effects. The actual coefficients and standard errors on non-labor income have been multiplied by 1,000. "Elasticity" refers to the implied elasticity of the dependent variable with respect to the ANTR, calculated at the means. $* * *$ denotes significance at $1 \% ; * *$ at $5 \%$; $*$ at $10 \%$. 
Table 2, Panel D: Dependent Variable is Weekly Residual Time

\begin{tabular}{|c|c|c|c|c|c|c|c|c|c|}
\hline & $\begin{array}{c}(1) \\
\text { Basic } \\
\text { Controls }\end{array}$ & $\begin{array}{c}(2) \\
\text { Control } \\
\text { for Self- } \\
\text { Selection }\end{array}$ & $\begin{array}{c}(3) \\
\text { Control } \\
\text { for } \\
\text { Welfare }\end{array}$ & $\begin{array}{c}(4) \\
\text { Sample is } \\
\text { pre-1993 }\end{array}$ & $\begin{array}{c}\text { (5) } \\
\text { IV for } \\
\text { Non- } \\
\text { Labor } \\
\text { Income }\end{array}$ & $\begin{array}{l}\text { (6) } \\
\text { IV for } \\
\text { ANTR }\end{array}$ & $\begin{array}{c}\text { (7) } \\
\text { IV for } \\
\text { Net-of- } \\
\text { Tax } \\
\text { Wage }\end{array}$ & $\begin{array}{c}(8) \\
\text { Extra } \\
\text { Controls }\end{array}$ & $\begin{array}{c}\text { (9) } \\
\text { Extra } \\
\text { Fixed } \\
\text { Effects }\end{array}$ \\
\hline ANTR & $\begin{array}{l}-4.21 \\
(4.93)\end{array}$ & $\begin{array}{l}-9.30 \\
(7.77)\end{array}$ & $\begin{array}{l}-3.80 \\
(4.89)\end{array}$ & $\begin{array}{c}-15.64 \\
(10.80)\end{array}$ & $\begin{array}{l}-2.49 \\
(6.59)\end{array}$ & $\begin{array}{c}-10.68 \\
(12.43)\end{array}$ & & $\begin{array}{c}-4.61 \\
(5.37)\end{array}$ & $\begin{array}{c}2.77 \\
(6.42)\end{array}$ \\
\hline Non-Labor Inc. & $\begin{array}{l}.006 \\
(.06)\end{array}$ & $\begin{array}{l}.006 \\
(.06)\end{array}$ & $\begin{array}{c}.005 \\
(.056)\end{array}$ & $\begin{array}{l}-.016 \\
(.074)\end{array}$ & $\begin{array}{c}2.25 \\
(1.57)\end{array}$ & $\begin{array}{l}.005 \\
(.06)\end{array}$ & $\begin{array}{l}.007 \\
(.06)\end{array}$ & $\begin{array}{c}.021 \\
(.058)\end{array}$ & $\begin{array}{c}.035 \\
(.055)\end{array}$ \\
\hline Welfare ATR & & & $\begin{array}{l}-2.22 \\
(2.00)\end{array}$ & $\begin{array}{c}-.95 \\
(2.88)\end{array}$ & $\begin{array}{c}.82 \\
(3.15)\end{array}$ & & & $\begin{array}{l}-2.04 \\
(2.17)\end{array}$ & \\
\hline Net Wage & & & & & & & $\begin{array}{l}-.28 \\
(.32)\end{array}$ & & \\
\hline R-Squared & .03 & .03 & .03 & .02 & & & & .04 & .23 \\
\hline $\mathrm{N}$ & 9,242 & 9,242 & 9,242 & 5,736 & 9,242 & 9,242 & 9,242 & 9,242 & 9,242 \\
\hline Elasticity & -.03 & -.07 & -.03 & -.12 & -.02 & -.08 & -.03 & -.04 & .02 \\
\hline
\end{tabular}

Notes: "Weekly residual time" is defined as time not spent on housework or market work. "ANTR" refers to the average net-of-tax rate, calculated using income imputed with demographics, as described in the text. The average net-of-tax rate is the percentage of income that a woman would keep if she participated in the labor force. Standard errors are clustered by individual. Each regression has 1,243 clusters. All regressions control for dummies for all possible values of age and number of children, as well as individual and year fixed effects; this is also the set of "basic controls" used in Column 1. Column 2 uses a Heckman selection correction in imputing income, as described in the text. Column 3 controls for the incentives created by AFDC, TANF, and food stamps. These incentives are summarized by the variable "Welfare ATR," which is equal to the difference between welfare benefits if a woman works and does not, as a fraction of the woman's earnings if she works. Column 4 limits the sample to the period before 1993. Column 5 instruments for non-labor income with the value of the welfare benefits a woman would receive if she did not work. Column 6 instruments for one measure of the average net-of-tax share using another measure, as described in the text. Column 7 instruments for the net-of-tax wage using the average net-of-tax share. Column 8 adds controls for the state minimum wage, state GDP, the presence of a welfare waiver, average labor income interacted with year, and education-by-year fixed effects. Column 9 adds number-of-childby-year, number-of-child-by-state, and state-by-year fixed effects. The actual coefficients and standard errors on non-labor income have been multiplied by 1,000 . "Elasticity" refers to the implied elasticity of the dependent variable with respect to the ANTR, calculated at the means. *** denotes significance at $1 \% ; * *$ at $5 \% ; *$ at $10 \%$. 
Table 3. PSID Heterogeneity Analysis: OLS regressions of time allocation outcome on imputed average net-of-tax share, non-labor income, individual fixed effects, and control variables. Dependent variable shown in column heading

\begin{tabular}{|c|c|c|c|c|c|c|c|c|c|c|c|c|}
\hline & \multicolumn{3}{|c|}{ Age Under 40} & \multicolumn{3}{|c|}{ Age 40 and Over } & \multicolumn{3}{|c|}{ No Children } & \multicolumn{3}{|c|}{ At Least One Child } \\
\hline & (1) & (2) & (3) & (4) & (5) & (6) & (7) & (8) & (9) & $(10)$ & $(11)$ & (12) \\
\hline & Weekly & Weekly & Weekly & Weekly & Weekly & Weekly & Weekly & Weekly & Weekly & Weekly & Weekly & Weekly \\
\hline & Hours & House- & Residual & Hours & House- & Residual & Hours & House- & Residual & Hours & House- & Residual \\
\hline & Worked & work & Time & Worked & work & Time & Worked & work & Time & Worked & work & Time \\
\hline \multirow[t]{2}{*}{ ANTR } & 23.06 & -14.84 & -8.22 & 9.04 & -6.83 & -2.21 & 51.30 & -11.41 & -39.90 & 14.63 & -13.56 & -1.07 \\
\hline & $(7.07) * * *$ & $(3.10) * * *$ & $(6.86)$ & $(7.58)$ & $(3.73)^{*}$ & $(8.75)$ & $(24.68)^{* *}$ & $(9.37)$ & $(26.36)$ & $(5.23) * * *$ & $(2.84) * * *$ & $(5.35)$ \\
\hline Non- & .059 & .034 & -.093 & -.065 & .001 & .064 & .053 & -.027 & -.025 & -.10 & .062 & .041 \\
\hline Lab. Inc. & $(.097)$ & $(.042)$ & $(.096)$ & $(.080)$ & $(.024)$ & $(.080)$ & $(.069)$ & $(.021)$ & $(.067)$ & $(.09)$ & $(.032)^{*}$ & $(.090)$ \\
\hline R-Sq. & .04 & .08 & .02 & .04 & .05 & .04 & .05 & .02 & .05 & .05 & .12 & .03 \\
\hline $\mathrm{N}$ & 5,275 & 5,275 & 5,275 & 3,857 & 3,857 & 3,857 & 3,651 & 3,651 & 3,651 & 5,591 & 5,591 & 5,591 \\
\hline Elas. & .55 & -.99 & -.06 & .21 & -.45 & -.02 & 1.17 & -.78 & -.28 & .33 & -.93 & -.01 \\
\hline
\end{tabular}

Notes: "ANTR" refers to the average net-of-tax rate, calculated using income imputed with demographics, as described in the text. Standard errors are clustered by individual. All regressions control for dummies for all possible values of age and number of children, as well as individual and year fixed effects. See other notes to Table 2. The total sample size is smaller than in Table 2 because singletons are dropped from the regressions, and the set of singletons is larger when a subset of the data is used. The actual coefficients and standard errors on non-labor income have been multiplied by 1,000 . "Elas." refers to the implied elasticity of the dependent variable with respect to the ANTR, calculated at the means. *** denotes significance at $1 \%$; ** at $5 \%$; at $10 \%$. 
Table 4. Time Use Data: OLS regressions of time allocation outcome on imputed average net-of-tax share and control variables. Dependent variable shown in column heading

\begin{tabular}{|c|c|c|c|c|c|c|c|c|c|c|c|c|}
\hline & $\begin{array}{c}(1) \\
\text { LFP }\end{array}$ & $\begin{array}{c}\text { (2) } \\
\text { Hours } \\
\text { Worked }\end{array}$ & $\begin{array}{c}(3) \\
\text { House- } \\
\text { work }\end{array}$ & $\begin{array}{c}\text { (4) } \\
\text { Home } \\
\text { Prod- } \\
\text { uction }\end{array}$ & $\begin{array}{c}(5) \\
\text { Non- } \\
\text { Market } \\
\text { Work }\end{array}$ & $\begin{array}{c}\text { (6) } \\
\text { Leisure } \\
1\end{array}$ & $\begin{array}{c}(7) \\
\text { Leisure } \\
2\end{array}$ & $\begin{array}{c}(8) \\
\text { Leisure } \\
3\end{array}$ & $\begin{array}{c}\text { (9) } \\
\text { Food } \\
\text { Prep and } \\
\text { Eating }\end{array}$ & $\begin{array}{l}\text { (10) } \\
\text { Child } \\
\text { Care }\end{array}$ & $\begin{array}{c}(11) \\
\text { Sleep }\end{array}$ & $\begin{array}{c}\text { (12) } \\
\text { Eating, } \\
\text { Sleep, } \\
\text { Personal } \\
\text { Care }\end{array}$ \\
\hline ANTR & $\begin{array}{c}.59 \\
(0.22) * * *\end{array}$ & $\begin{array}{c}30.01 \\
(14.00)^{* *}\end{array}$ & $\begin{array}{c}-11.14 \\
(5.37)^{* *}\end{array}$ & $\begin{array}{c}-18.80 \\
(7.26)^{* *}\end{array}$ & $\begin{array}{c}-18.41 \\
(8.45)^{* *}\end{array}$ & $\begin{array}{l}-16.09 \\
(13.19)\end{array}$ & $\begin{array}{c}-22.99 \\
(13.09)^{*}\end{array}$ & $\begin{array}{l}-15.77 \\
(13.80)\end{array}$ & $\begin{array}{c}-8.24 \\
(4.53)^{*}\end{array}$ & $\begin{array}{c}7.22 \\
(5.30)\end{array}$ & $\begin{array}{l}-2.82 \\
(9.26)\end{array}$ & $\begin{array}{c}-6.91 \\
(10.10)\end{array}$ \\
\hline $\begin{array}{l}\mathrm{R}-\mathrm{Sq} . \\
\mathrm{N} \\
\text { Elas. }\end{array}$ & $\begin{array}{c}.22 \\
4,444 \\
.74 \\
\end{array}$ & $\begin{array}{c}.09 \\
4,444 \\
1.03 \\
\end{array}$ & $\begin{array}{c}.08 \\
4,444 \\
-1.71 \\
\end{array}$ & $\begin{array}{c}.12 \\
4,444 \\
-1.25 \\
\end{array}$ & $\begin{array}{c}.08 \\
4,444 \\
-.87 \\
\end{array}$ & $\begin{array}{c}.05 \\
4,444 \\
-.45 \\
\end{array}$ & $\begin{array}{c}.06 \\
4,444 \\
-.20 \\
\end{array}$ & $\begin{array}{c}.07 \\
4,444 \\
-.13 \\
\end{array}$ & $\begin{array}{c}.14 \\
4,444 \\
-.63 \\
\end{array}$ & $\begin{array}{c}.24 \\
4,444 \\
1.38\end{array}$ & $\begin{array}{c}.05 \\
4,444 \\
-.04\end{array}$ & $\begin{array}{c}.05 \\
4,444 \\
-.09 \\
\end{array}$ \\
\hline
\end{tabular}

Notes: The table shows the effect of the Average Net-of-Tax Rate (ANTR) on the weekly amount of time spent on each activity in question. The data are the repeated cross sections of time use data in Aguiar and Hurst (2007), in addition to the 2004 American Time Use survey. "LFP" refers to labor force participation. The definitions of the time use outcomes can be found in Section 2 . All regressions control for dummies for year, five education categories, and all possible values of age and number of children. "Elas." refers to the implied elasticity of the dependent variable with respect to the ANTR, calculated at the means. *** denotes significance at $1 \% ; * *$ at $5 \%$; $*$ at $10 \%$. 
Table 5. Expenditure Data: OLS regressions of expenditure category on imputed average net-of-tax share and control variables. Dependent variable shown in column heading

\begin{tabular}{|c|c|c|c|c|c|c|c|}
\hline & $\begin{array}{c}(1) \\
\text { Total Food } \\
\text { (PSID) }\end{array}$ & $\begin{array}{c}(2) \\
\text { Total Food } \\
\text { (CEX) }\end{array}$ & $\begin{array}{c}\text { (3) } \\
\text { Food at Home }\end{array}$ & $\begin{array}{c}\text { (4) } \\
\text { Food Away } \\
\text { from Home }\end{array}$ & $\begin{array}{c}\text { (5) } \\
\text { Food at Work }\end{array}$ & $\begin{array}{c}(6) \\
\text { Domestic } \\
\text { Services }\end{array}$ & $\begin{array}{c}(7) \\
\text { Major } \\
\text { Appliances }\end{array}$ \\
\hline ANTR & $\begin{array}{c}1,963.08 \\
(1,737.87)\end{array}$ & $\begin{array}{c}-19.47 \\
(227.28)\end{array}$ & $\begin{array}{c}-417.85 \\
(173.17)^{* *}\end{array}$ & $\begin{array}{c}340.80 \\
(99.84)^{* * * *}\end{array}$ & $\begin{array}{c}57.58 \\
(22.24)^{* *}\end{array}$ & $\begin{array}{c}62.06 \\
(99.51)\end{array}$ & $\begin{array}{c}27.72 \\
(35.89)\end{array}$ \\
\hline Capital Income & $\begin{array}{l}.04 \\
(.02) \\
\end{array}$ & $\begin{array}{c}.04 \\
(.01)^{* * *}\end{array}$ & $\begin{array}{c}.03 \\
(.004)^{* * *}\end{array}$ & $\begin{array}{c}.02 \\
(.003)^{* * *}\end{array}$ & $\begin{array}{l}-.0004 \\
(.0003)\end{array}$ & $\begin{array}{c}.01 \\
(.003)^{* * *}\end{array}$ & $\begin{array}{c}.003 \\
(.001)^{* * *}\end{array}$ \\
\hline R-Squared & .01 & .12 & .18 & .09 & .01 & .05 & .02 \\
\hline $\mathrm{N}$ & 8,293 & 25,395 & 25,395 & 25,395 & 25,395 & 25,395 & 25,395 \\
\hline Elasticity & .33 & -.006 & -.18 & .44 & 2.03 & .24 & .28 \\
\hline \multicolumn{8}{|c|}{$\begin{array}{l}\text { Notes: The table shows the effect of the Average Net-of-Tax Rate (ANTR) on expenditures on different items, expressed in real } 2005 \text { dollars. } \\
\text { Column } 1 \text { is based on PSID expenditure data; food expenditures are calculated by summing food at home and food away from home. Columns } \\
\text { through } 7 \text { are based on Consumer Expenditure Survey data. Total food, food away from home, food at home, and food at work are coded to be } \\
\text { consistent with the National Income and Product Accounts expenditure categories. Total food is calculated by summing food away from home } \\
\text { food at home, and food at work. CEX data are taken from the CEX interview files. All regressions control for dummies for year, five educatio } \\
\text { categories, and all possible values of age and number of children. In Column } 1 \text { we also include individual fixed effects and cluster the standarc } \\
\text { errors at the individual level. "Elasticity" refers to the implied elasticity of the dependent variable with respect to the ANTR, calculated at the } \\
\text { means. *** denotes significance at } 1 \% ; * * \text { at } 5 \% ; * \text { at } 10 \% \text {. }\end{array}$} \\
\hline
\end{tabular}


Appendix Table 1. Alternative specifications: Dependent variable shown in column heading

\begin{tabular}{|c|c|c|c|c|c|c|}
\hline & $\begin{array}{c}\text { (1) } \\
\text { Yearly Hours } \\
\text { Worked }\end{array}$ & $\begin{array}{c}(2) \\
\text { Currently } \\
\text { Working }\end{array}$ & $\begin{array}{c}\text { (3) } \\
\text { Positive Yearly } \\
\text { Hours of Work }\end{array}$ & $\begin{array}{c}\text { (4) } \\
\text { Weekly Hours } \\
\text { Worked }\end{array}$ & $\begin{array}{c}\text { (5) } \\
\text { Weekly } \\
\text { Housework }\end{array}$ & $\begin{array}{c}\text { (6) } \\
\text { Weekly Other } \\
\text { Time }\end{array}$ \\
\hline ANTR & $\begin{array}{c}839.17 \\
(236.85) * * *\end{array}$ & $\begin{array}{c}.41 \\
(.11)^{* * *}\end{array}$ & $\begin{array}{c}.44 \\
(.08)^{* * *}\end{array}$ & & & \\
\hline $\begin{array}{l}\text { Participation } \\
\text { Dummy }\end{array}$ & & & & $\begin{array}{c}35.87 \\
(.71)^{* * *}\end{array}$ & $\begin{array}{c}-4.71 \\
(.73) * * *\end{array}$ & $\begin{array}{c}-31.16 \\
(.94) * * *\end{array}$ \\
\hline $\begin{array}{l}\text { R-Squared } \\
\mathrm{N}\end{array}$ & $\begin{array}{c}.06 \\
9,242 \\
\end{array}$ & $\begin{array}{c}.04 \\
9,242 \\
\end{array}$ & $\begin{array}{c}.04 \\
9,242 \\
\end{array}$ & $\begin{array}{c}.41 \\
9,242\end{array}$ & $\begin{array}{c}.10 \\
9,242 \\
\end{array}$ & $\begin{array}{c}.26 \\
9,242 \\
\end{array}$ \\
\hline
\end{tabular}

Notes: "ANTR" refers to the average net-of-tax rate, calculated using income imputed with demographics, as described in the text. The average net-of-tax rate is the percentage of income that a woman would keep if she participated in the labor force. Standard errors are clustered by

individual. Each regression has 1,243 clusters. All regressions control for dummies for all possible values of age and number of children, as well as individual and year fixed effects. Yearly hours worked includes hours on secondary jobs and overtime hours. The "participation dummy" is a dummy that equals one if usual weekly hours worked is positive, zero otherwise. "Currently working" refers to a dummy that measures whether someone's employment status is "working now." "Positive yearly hours of work" is a dummy that equals one if the person reports working a positive number of hours over the course of the entire year. *** denotes significance at $1 \%$; ** at $5 \%$; at $10 \%$. 
Appendix Table 2. Food expenditure results with log of food expenditures as dependent variable: OLS regressions of log of food expenditures on imputed average net-of-tax share and control variables. Dependent variable shown in column heading

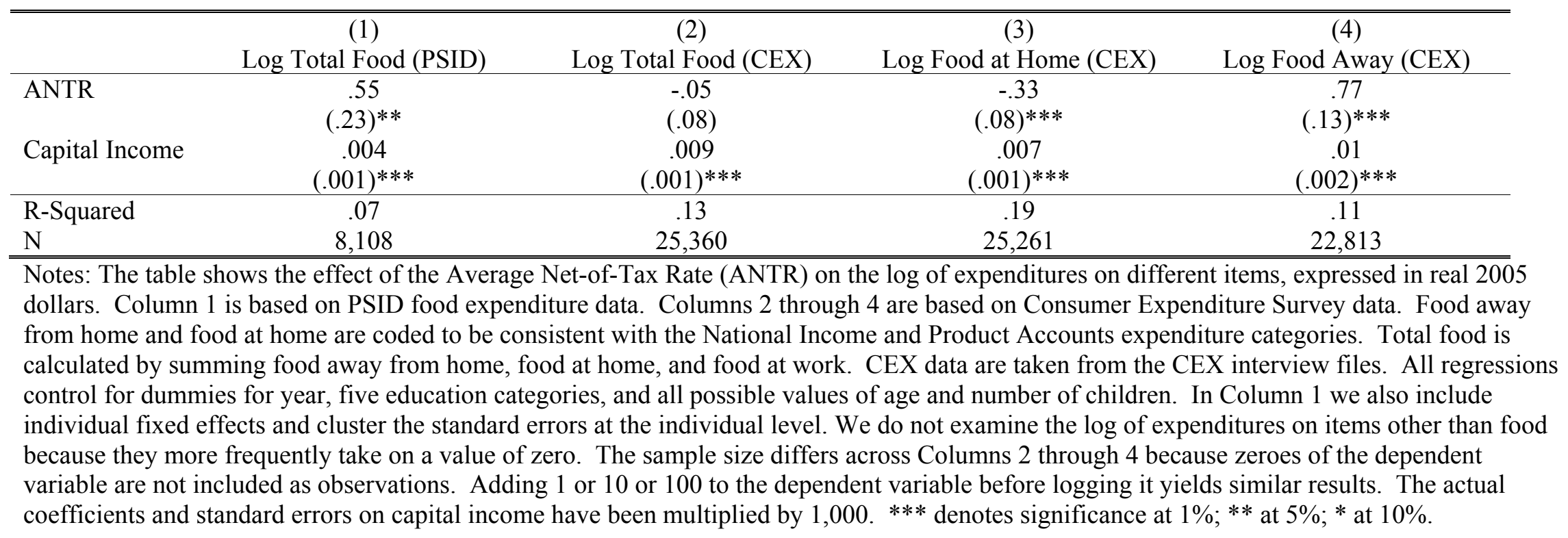

